\title{
Seasonal analysis of submicron aerosol in Old Delhi using high resolution aerosol mass spectrometry: Chemical characterisation, source apportionment and new marker identification
}

\section{Supplementary Information}

James M. Cash ${ }^{1,2}$, Ben Langford ${ }^{1}$, Chiara Di Marco ${ }^{1}$, Neil Mullinger ${ }^{1}$, James Allan ${ }^{3}$, Ernesto Reyes-Villegas ${ }^{3}$, Ruthambara Joshi ${ }^{3}$, Mathew R. Heal ${ }^{2}$,W. Joe F. Acton ${ }^{4, \Delta}$, Nick Hewitt ${ }^{4}$, Pawel

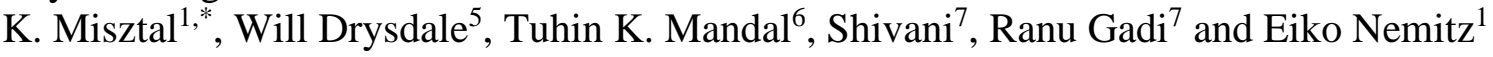

\footnotetext{
${ }^{1}$ UK Centre for Ecology \& Hydrology, Edinburgh Research Station, Penicuik, EH26 0QB, UK

${ }^{2}$ School of Chemistry, University of Edinburgh, Edinburgh, EH9 3FJ, Edinburgh, UK

${ }^{3}$ Department of Earth and Environmental Sciences, University of Manchester, Manchester, M13 9PL, UK

${ }^{4}$ Lancaster Environment Centre, Lancaster University, Lancaster, LA1 4YQ, UK

${ }^{5}$ Wolfson Atmospheric Chemistry Laboratory, University of York, York, YO10 5DD, UK

${ }^{6}$ CSIR National Physics Laboratory,

${ }^{7}$ Department of Applied Sciences and Humanities, Indira Gandhi Delhi Technical University for Women, Delhi, 110006, India

${ }^{\Delta}$ Now at: School of Geography, Earth and Environmental Sciences, University of Birmingham, Birmingham, UK

* Now at: Department of Civil, Architectural and Environmental Engineering, The University of Texas at Austin, Austin, TX 78712, USA
}

\section{S1. Method for determining the best Organic PMF solution}

This section describes the method for obtaining the organic-only PMF solution and the flow chart in Figure S1 illustrates the separate steps to the analysis. The details of each step are described in detail below. Four main complications arose when analysing this dataset using PMF:

1. The solutions changed with different initialisation SEEDS.

And decisions had to be made about:

2. whether to conduct PMF analysis on the separate periods (Pre-Monsoon, Monsoon, Post-Monsoon) individually, or whether to combine all the periods into one single PMF analysis,

3. whether to use the full recorded mass spectrum for the analysis or to cut off the spectrum at $<120 \mathrm{~m} / \mathrm{z}$,

4. On the number of factors PMF could distinguish.

PMF analysis was therefore conducted on the separate measurement periods (pre-monsoon, monsoon and post-monsoon) and on all the measurement periods combined. For each period, and the all-combined case, PMF was conducted on separate organic matrices which excluded or included peaks $>120 \mathrm{~m} / \mathrm{z}$. These analyses are respectively referred to as $<120 \mathrm{~m} / \mathrm{z}$ and $>120$ 
$m / z$ in Figure S1. The rotational ambiguity of each solution was explored (-3 to 3, steps of 0.2 ) and consistently showed little variation with different FPEAKs. This led to all solutions being set to FPEAK $=0$.

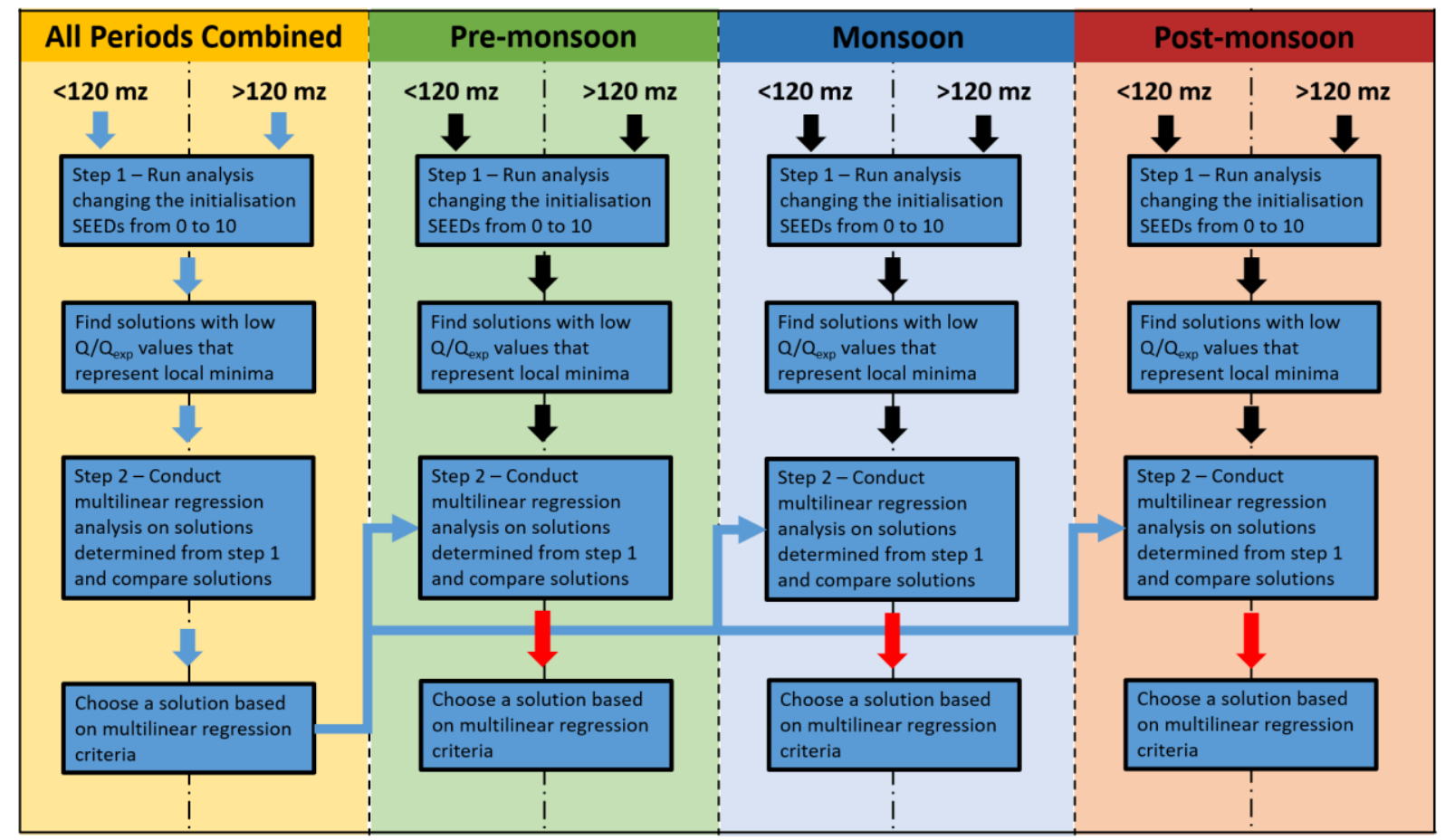

Figure S1 - Flow chart to show the steps to finding a PMF solution. First the analysis was conducted on the all periods combined case and these solutions were then compared with the step 2 analysis of each period separately, as illustrated with the blue arrows. The solution which matched the multilinear regression criteria more closely was then chosen, as illustrated by the red arrows.

\section{Step 1 - choose Q/Qexp local minima out of 0 to 10 initialisation SEEDS}

Initialisation SEEDS were explored from 0 to 10 for each analysis and almost all the solutions showed variation when the initialisation SEED was altered. Due to the large number of solutions this created, solutions were chosen from each set of 0 to 10 SEEDS based on their $\mathrm{Q} / \mathrm{Q}_{\exp }$. Chosen solutions showed $\mathrm{Q} / \mathrm{Q}_{\exp }$ values that were clear local minima in the solution space. Exceptions were made for S0 solutions as these represent a baseline solution for comparison. Some additional solutions were also chosen based on their chemical resemblance to source factors. Other solutions were removed due to obvious factor splitting, following a procedure described in detail in the supplementary information of Allan et al. (2010). They were then taken to the next step where they were compared using multilinear regression analysis.

Variation in the number of factors was also explored for each analysis. A set of between 5-7 factors was found to best describe the measurements without obvious time-series splitting. However, solutions with less obvious splitting were not fully explored until after multilinear regression analysis as this removes bias due to the user's choice in the number of factors, one of the largest forms of error in use of the PMF algorithm (Ulbrich et al., 2009). The time series splitting was further explored post-regression analysis. 


\section{Step 2 - Conduct multilinear regression analysis on solutions chosen from step 1}

In order to reduce the subjectivity of choosing a solution, they were compared using multilinear regression analyses where the factors were combined to fit an external tracer, ET (Allan et al., 2010; Young et al., 2015; Reyes-Villegas et al., 2016):

$$
E T=A+B(S F O A)+C(C O A)+D(H O A)
$$

The three external tracers used here were the concentrations of $\mathrm{NO}_{\mathrm{x}}, \mathrm{CO}$ and $\mathrm{BC}$ measured at the same site (only BC was available for the Monsoon period). The coefficients are valuable ways of verifying the solution fit where $A$ is an indication of the background concentration of the tracer. The other three coefficients, $B, C$ and $D$, are gradients to the fit which show the contribution of each factor.

The strategy to choosing a solution from multilinear regression analysis involves a search for a compromise of characteristics which is summarised as follows.

\section{Multilinear Regression Criteria:}

1. A solution with a low chi-square value shows a higher correlation of its multilinear fit with the $E T$

2. The solution should contain factors which contribute more strongly to certain ETs. This includes:

a. Strong contributions of $\mathrm{HOA}$ to $\mathrm{NO}_{\mathrm{x}}$ above all other factors

b. SFOA contribution close to or above zero for $\mathrm{BC}$

c. COA contribution close to or above zero for $\mathrm{BC}$

3. An estimated background concentration which is near background levels for the ET

4. A low $\mathrm{Q} / \mathrm{Q}_{\mathrm{exp}}$

The COA coefficient, $C$, has previously been expected to be near zero as cooking activities are not commonly associated with the production of $\mathrm{NO}_{\mathrm{x}}$ or $\mathrm{CO}$ (Reyes-Villegas et al., 2016). It may however be possible that burning of organic material contributes to COA in Delhi. Cooking food over open fires is a major practice in the city which is likely to produce $\mathrm{BC}$ and means COA and BC are likely to correlate. It is also suggested that $\mathrm{Q} / \mathrm{Q}_{\exp }$ should only be compared between solutions from the same period as the length of dataset will likely strongly influence this value. Additionally, an increase in number of factors will lower $\mathrm{Q} / \mathrm{Q}_{\exp }$ due to an increase in degrees of freedom. These two influences were therefore considered when choosing a solution.

The graphs in Figure S2 to Figure S5 show the different solutions chosen in step 1 along the $\mathrm{x}$ axis. They have specific labels such as "6f_ac_<120mz_S0_C1", where the ' $6 \mathrm{f}$ ' indicates it is a 6-factor solution, 'S0' indicates this is the solution found at SEED 0 and solutions with ' $<120 \mathrm{mz}$ ' in their name include ions up to $120 \mathrm{~m} / \mathrm{z}$. Those with 'ac' in their name have been resolved from the all-combined analysis case (all periods analysed in one PMF analysis). If the solution does not include prefixes 'ac' or ' $<120 \mathrm{mz}$ ', they include ions up to $328 \mathrm{~m} / \mathrm{z}$ and have not been resolved from the all-combined case. Solutions with ' $\mathrm{C} 1$ ' indicates a specific combination of factors used for the SFOA variable in Eq. (S1). The SFOA variable could be an SFOA factor time series alone $(\mathrm{C} 1)$ or a combined time series of an SFOA and an SVBBOA factor (C2), if both were resolved in the solution. The SVBBOA factors had secondary characteristics and the SFOA factors were primary and as a result, they caused significantly 
different fit results when combined or separated. In order to remove any bias resulting from this, these combinations were explored at this stage rather than later.

The post-monsoon period analysis (Figure S5) also produce solutions with two SFOA factors. The two SFOA factors were therefore combined to give SFOA (= SFOA1 + SFOA2) and these solutions are labelled ' $\mathrm{C} 3$ '.

The high signals seen at masses $>120 \mathrm{~m} / \mathrm{z}$ carry important information such as PAH composition. Similar PMF analyses have been conducted where the solution fit was improved through the addition of masses up to $385 \mathrm{~m} / \mathrm{z}$ (Aiken et al., 2009; Docherty et al., 2011; Sun et al., 2016; Zhang et al., 2018). In order to validate this, every possible solution obtained using a $>120 \mathrm{~m} / \mathrm{z}$, solution was compared to a $<120 \mathrm{~m} / \mathrm{z}$ solution.

The strategy to finding the final solution first involved finding the most robust solutions for the all-combined case to then compare with the period-specific analyses (Figure S1). Figure S2(a) shows the $\mathrm{CO}$ trilinear analyses for the all-combined case where COA consistently contributes negatively to the fit for all solutions. COA may therefore have little importance when considering a solution for the $\mathrm{CO}$ fit. The SFOA contribution has a large range between solutions and its significance is uncertain without prior knowledge. The chi-square value is therefore a better indication of the most accurate solution to fit $\mathrm{CO}$. The two solutions with the lowest chi-square values are 7f_ac_S1_C1 and 7f_ac_S1_C2. For the $\mathrm{NO}_{\mathrm{x}}$ analysis in Figure S2(b), There is a similar set of contributions for each factor and a consistently strong contribution of the traffic factor, HOA. The chi-square is again an important parameter for choosing the best solution. The same two solutions give the lowest values: 7f_ac_S1_C1 and 7f_ac_S1_C2.

In Figure S2(c), the contribution of factors to BC varies, with some solutions showing above or near zero COA contribution. Using the multilinear regression criteria described above, a number of solutions can therefore be chosen including: 7f_ac_<120mz_S0_C1, 7f_ac_<120mz_S0_C2, 7f_ac_<120mz_S1_C1, 7f_ac_<120mz_S1_C2, 7f_ac_S0_C1, 7f_ac_S1_C1,7f_ac_S1_C2,6f_ac_<120mz_S0_C1 and 6f_ac_<120mz_S0_C2.Considering that both 7f_ac_S1_C1 and 7f_ac_S1_C2 were the most robust in the $\mathrm{NO}_{\mathrm{x}}$ and $\mathrm{CO}$ analyses as well, these solutions are likely the most robust solutions. However, each $\mathrm{C} 1$ solution has a lower chi-square value which suggests that the burning-related factors fit ETs stronger when separated.7f_ac_S1_C1 is therefore the chosen solution for the all-combined case.

In order to account for differences in composition between the three periods, seven of the solutions were taken from the all-combined case to compare with the separate period analyses. Five of the $\mathrm{C} 1$ solutions in the list above were used, along with the two solutions: 6f_ac_S0 and 6f_ac_S3, in order to add comparisons of 6f solutions with masses $>120 \mathrm{~m} / \mathrm{z}$. The same method was then used to determine the most robust solution for the separate period analyses. The Monsoon period analysis includes only BC as an external tracer because measurements of other tracers were not available. The solution with the strongest fit to external tracers for the pre-monsoon (Figure S3) and monsoon periods (Figure S4) is the all-combined case solution, 7f_ac_S1_C1. In Figure S5, there are however two solutions for the post-monsoon (7f_ac_S1_C1 and 6f_<120mz_S0_C3) which are very similar in their trilinear analysis parameters and both are near equal in their fit to external tracers. As both are valid solutions, 
the chosen solution is 7f_ac_S1_C1 as it represents the primary factors well in the two other periods and it also maintains consistency in representing organic source factors for Old Delhi.

It should be noted that the calculation of a common PMF solution for the combined dataset was possible because luckily no major interventions to the instrument were required during the measurements that would could have caused a change in the relative sensitivities to the various ions, such as change of filaments, venting of the instrument, or major retuning of the mass spectrometer.
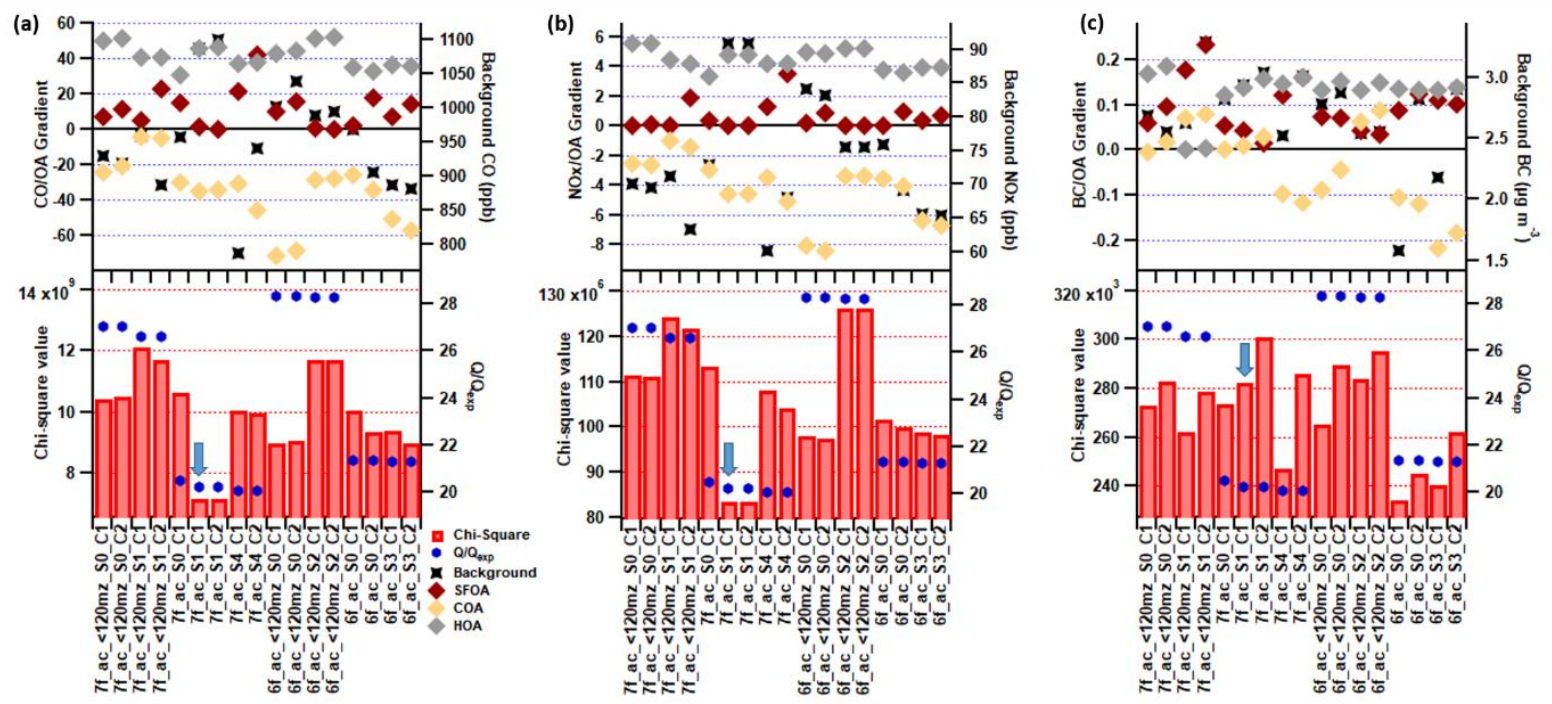

Figure S2 - Trilinear regression analysis results for the PMF solutions taken from the allperiods-combined case. Results are shown for the fit using (a) $\mathrm{CO}$, (b) $\mathrm{NO}_{\mathrm{x}}$ and (c) $\mathrm{BC}$ as external tracers. The chi-square value for the fit is shown using red markers and the Q/Qexp with blue markers. Gradient contributions for factors SFOA, COA and HOA are shown alongside the background concentration for the tracer. The final solution chosen is labelled with a blue arrow. 

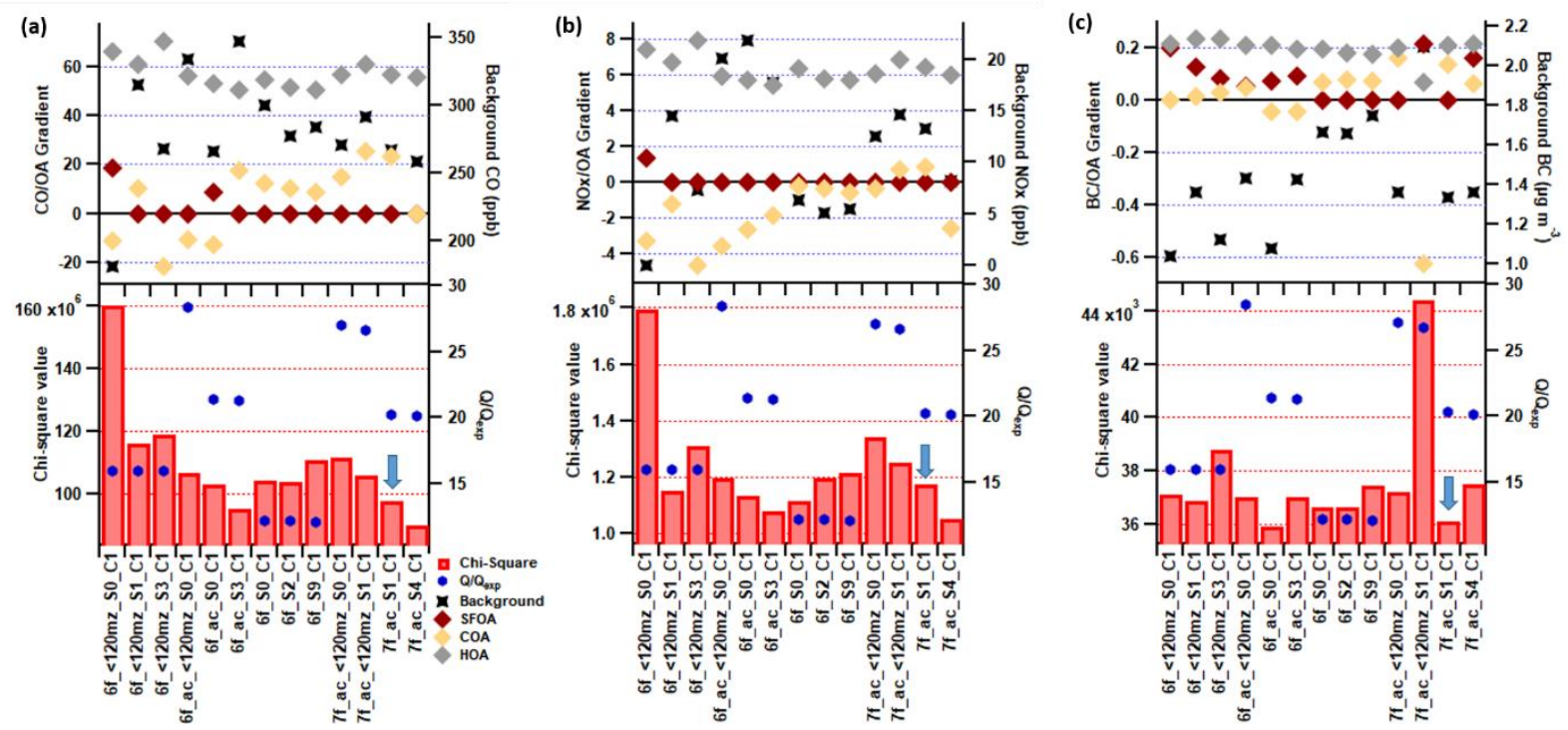

Figure S3 - Trilinear regression analysis results for the Pre-Monsoon period analysis. Solutions with ' $a c$ ' in their name are taken from the all-combined-period analysis case and only the Pre-Monsoon data is inputted into the trilinear analysis. Solutions without 'ac' are Pre-Monsoon only PMF solutions. Results are shown for the fit using (a) CO, (b) $\mathrm{NO}_{\mathrm{x}}$ and (c) $\mathrm{BC}$ as external tracers. The chi-square value for the fit is shown using red bars and the $Q / Q_{\text {exp }}$ with blue markers. Gradient contributions for factors SFOA, COA and HOA are shown alongside the background concentration for the tracer. The final solution chosen is labelled with a blue arrow.

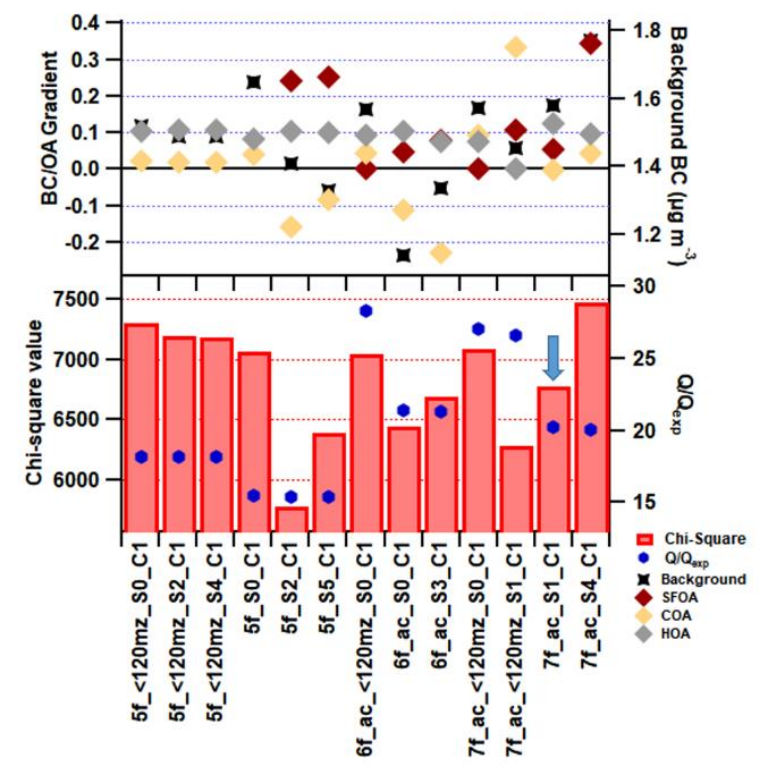

Figure S4 - Bi- and trilinear regression analysis results for the Monsoon period where solutions with 'ac' in their name are taken from the all-combined-period analysis case and only the Monsoon data is inputted into the trilinear analysis. Results are for the fit using $\mathrm{BC}$ as external tracer. The chi-square value for the fit is shown using red bars and the Q/Qexp with blue markers. Gradient contributions for factors SFOA, COA and HOA are shown alongside the background concentration for the tracer. The final solution chosen is labelled with a blue arrow. 

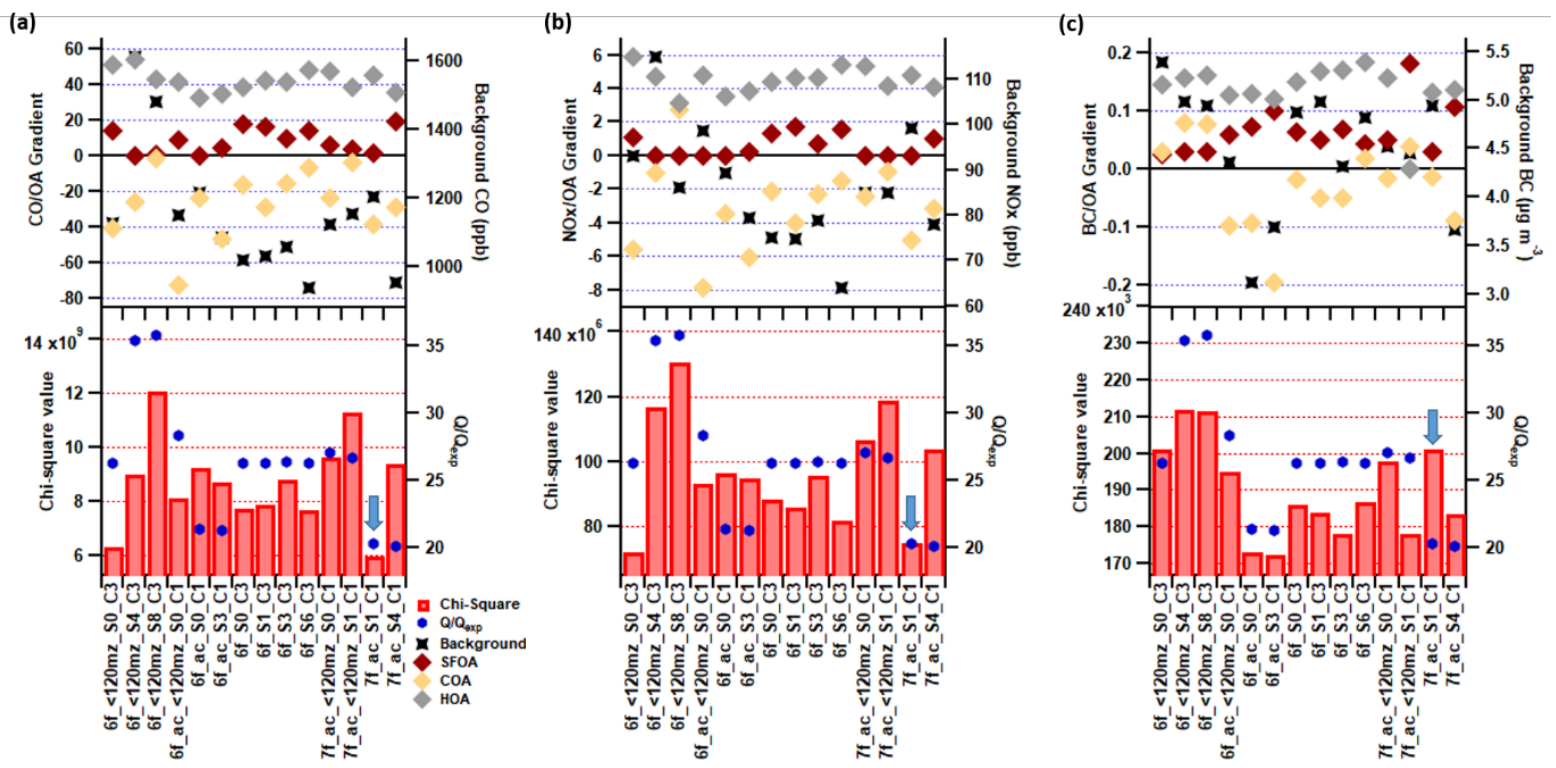

Figure S5 - Trilinear regression analysis results for the Post-Monsoon period analysis. Solutions with 'ac' in their name are taken from the all-combined-period analysis case and only the Post-Monsoon data is inputted into the trilinear analysis. Results are shown for the fit using (a) $\mathrm{CO}$, (b) $\mathrm{NO}_{\mathrm{x}}$ and (c) $\mathrm{BC}$ as external tracers. The chi-square value for the fit is shown using red bars and the $Q / Q \exp$ with blue markers. Gradient contributions for factors SFOA, COA and HOA are shown alongside the background concentration for the tracer. The final solution chosen is labelled with a blue arrow.

\section{S2. - Determining if the traffic factors (NHOA and HOA) and burning factors (SFOA and SVBBOA) are more meaningful if separated or combined}

As shown in the previous section, the separation of burning-related factors gave larger correlations with the external tracers. However, the SVBBOA factor was not included to simplify the analysis. This section includes a separate variable for SVBBOA in order to further establish if SFOA and SVBBOA should be separated or combined to form one time series. Similarly, the difference between the traffic factors NHOA and HOA is also investigated to see if the two create a better fit to external tracers when separated or when combined, to assess how robust the identified NHOA factor is. This analysis was applied to the chosen solution (7f_ac_S1_C1) and using Pearson's r correlations shown in Table S1, the two traffic factors showed a negligible change in correlation with external tracers when separated or combined. Similarly, the two burning factors showed little improvement in correlations when combined. Therefore, further multilinear regression analysis was carried out.

Penta- and tetralinear analyses were carried out using similar equations to Eq. (S1) but the number of factors, and therefore coefficients, were increased. The pentalinear equation is of the form:

$$
E T=A+B(S F O A)+C(C O A)+D(H O A)+E(N H O A)+F(S V B B O A),
$$


which does not include a combination of factors. The two tetralinear analyses correspond to two different combinations of factors. The Tetra_B1 analysis uses the equation:

$$
E T=A+B(S F O A)+C(C O A)+D\left(H O A_{t o t}\right)+E(S V B B O A)
$$

where $H O A_{t o t}$ is the sum of NHOA and HOA. The Tetra_B2 analysis uses the equation:

$$
E T=A+B\left(S F O A_{t o t}\right)+C(C O A)+D(H O A)+E(N H O A),
$$

where $S F O A_{t o t}=\mathrm{SFOA}+\mathrm{SVBBOA}$. The trilinear analysis uses Eq. (S1) with combinations $C O A, H O A_{t o t}$ and $S F O A_{\text {tot }}$. These results are shown in Figure S6 and the chi-square values are summarised in Table S1 where a decrease in the chi-square is seen for the pentalinear analysis, i.e. when NHOA and HOA are separated, and this suggests that they are separate source factors. It also supports the findings shown in Section $\mathrm{S} 1$ as the chi-square decreases when SFOA and SVBBOA are separated. Additionally, Figure S6 also shows a significant difference in contribution based on the external tracer BC. The contribution of NHOA to BC in the Penta and Tetra_B2 analyses is particularly low but the HOA contribution is high. This further supports that they are from different sources.

Table S1 - External tracer correlation summary showing the Pearson's r correlations for the traffic-related (NHOA and HOA) and burning-related (SFOA and SVBBOA) factors when their time series are combined (e.g. SFOA tot $=$ SFOA + SVBBOA) or separated. The chi-square values for the multilinear regression analyses are also summarised for the Tri,

\begin{tabular}{|c|c|c|c|c|}
\hline Pearson's r correlations & $\mathrm{CO}$ & $\mathrm{NO}_{x}$ & $B C$ & Acetonitrile \\
\hline SFOA & 0.460 & 0.376 & 0.551 & 0.749 \\
\hline SVBBOA & 0.531 & 0.447 & 0.618 & 0.607 \\
\hline$S F O A_{t o t}=S F O A+S V B B O A$ & 0.547 & 0.451 & 0.642 & 0.758 \\
\hline NHOA & 0.850 & 0.770 & 0.697 & 0.735 \\
\hline HOA & 0.879 & 0.853 & 0.637 & 0.685 \\
\hline$H O A_{t o t}=H O A+N H O A$ & 0.911 & 0.855 & 0.701 & 0.725 \\
\hline Chi-squared - Multilinear Regressions & $\mathrm{CO}$ & $N O_{x}$ & $B C$ & \\
\hline$E T(T r i)-S F O A=S F O A_{t o t}$ and $H O A=H O A_{t o t}$ & $7.18 \mathrm{e}+9$ & $8.38 \mathrm{e}+7$ & $2.82 \mathrm{e}+5$ & - \\
\hline$E T\left(T e t r a \_B 1\right)-S F O A=S F O A_{t o t}$ & $7.12 \mathrm{e}+9$ & $8.19 \mathrm{e}+7$ & $2.38 \mathrm{e}+5$ & - \\
\hline$E T\left(T e t r a \_B 2\right)-H O A=H O A_{t o t}$ & $7.14 \mathrm{e}+9$ & $8.10 e+7$ & $2.42 e+5$ & - \\
\hline ET(Penta) - all separated & $7.11 e+9$ & $8.10 e+7$ & $2.27 e+5$ & - \\
\hline
\end{tabular}
Tetra_B1, Tetra_B2 and Penta cases (see Section S2 for explanation). 

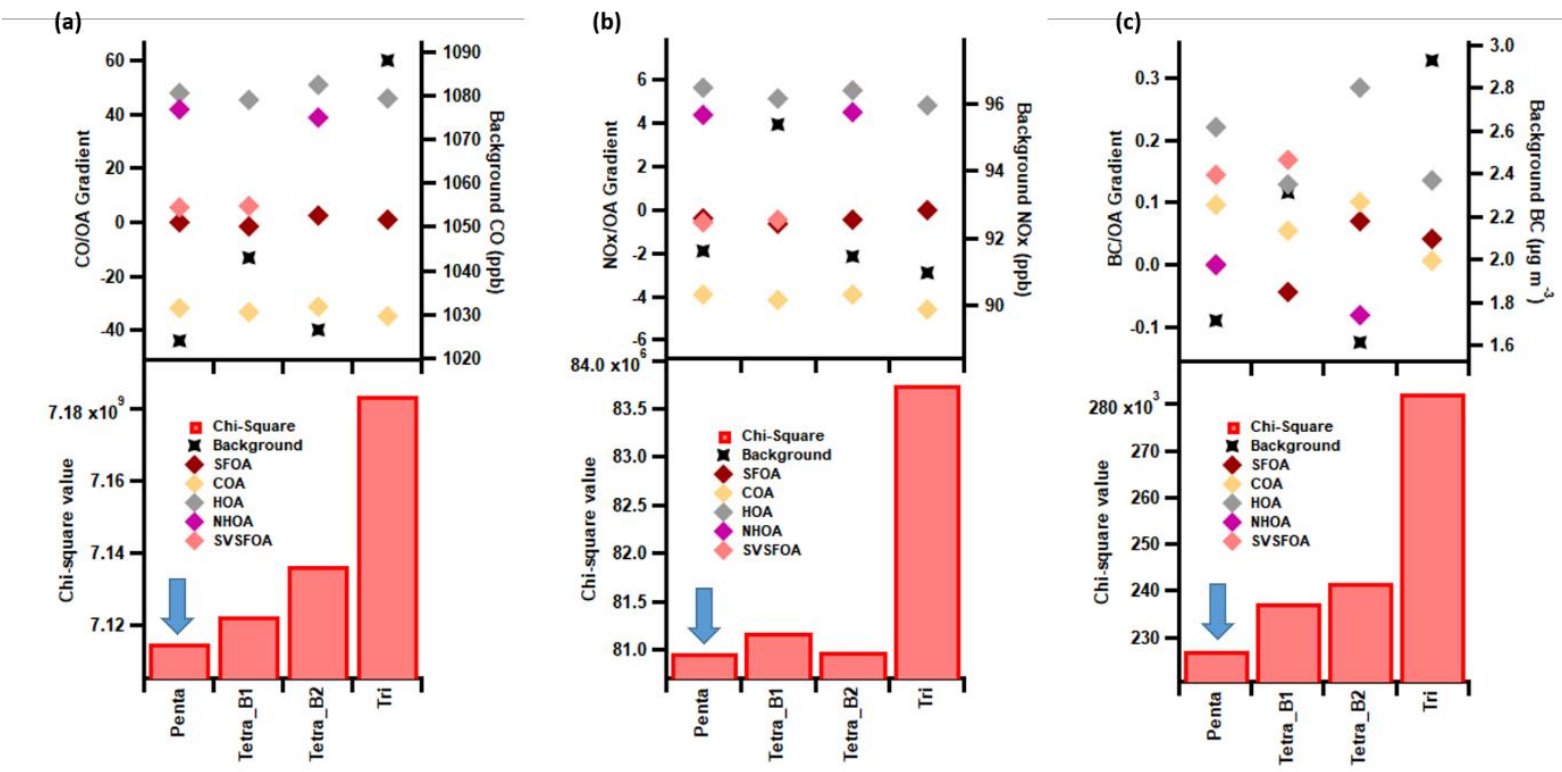

Figure S6 - Multilinear regression analysis results for 7f_ac_S1 solution showing four difference combinations of factors. Results are shown for the fit using (a) $\mathrm{CO}$, (b) $\mathrm{NO}_{\mathrm{x}}$ and (c) BC as external tracers. The chi-square value for the fit is shown in red. Gradient contributions for factors are coloured according to the legend and the background concentration for the tracer is black. The final solution chosen is labelled with a blue arrow.

\section{S2. Method for determining the Inorganic-Organic PMF solution}

The method described in Section S1 for the organic PMF analysis was also applied to the InorgOrg PMF solutions. In brief, the previous organics analysis showed that a more robust solution is produced using all the measurement periods combined and including the larger masses $(>120$ $\mathrm{m} / \mathrm{z}$ ). This was therefore carried into the Inorg-Org PMF analysis. The rotational ambiguity was explored and again showed little variation between FPEAKS ( -2 to 2, steps of 0.2 ). The mass contributions are the same to $0.1 \%$ between FPEAKS which lead to setting FPEAK $=0$.

Through exploring different initialisation SEEDS, the solutions changed, and multilinear regression analysis was carried out in the same method as described in Section S1. The results are summarised in Figure S7 and the same three external tracers were used. The organic PMF analysis in Section S1 and Section S2 also determined that, in most cases, the solution correlated with external tracers more strongly when factors were separated. The regression variables therefore increase with the number of factors and there are up to 6 variables used in the fit. The factors chosen for the fit are primary in nature and those that were not identifiable are labelled as primary organic aerosol (POA). 
The solution chosen was 9f_S3 which gave a close to zero COA factor contribution and consistently gave low chi-square values for all three tracers. The solution 10f_S5 is an equally strong solution but there is not enough a priori information to discern if there is a credible separation into 10 factors i.e. unknown or non-specific factors were resolved past 9 factors. Additionally, the 9f_S3 is the most comparable to the organic-only PMF solution chosen. 

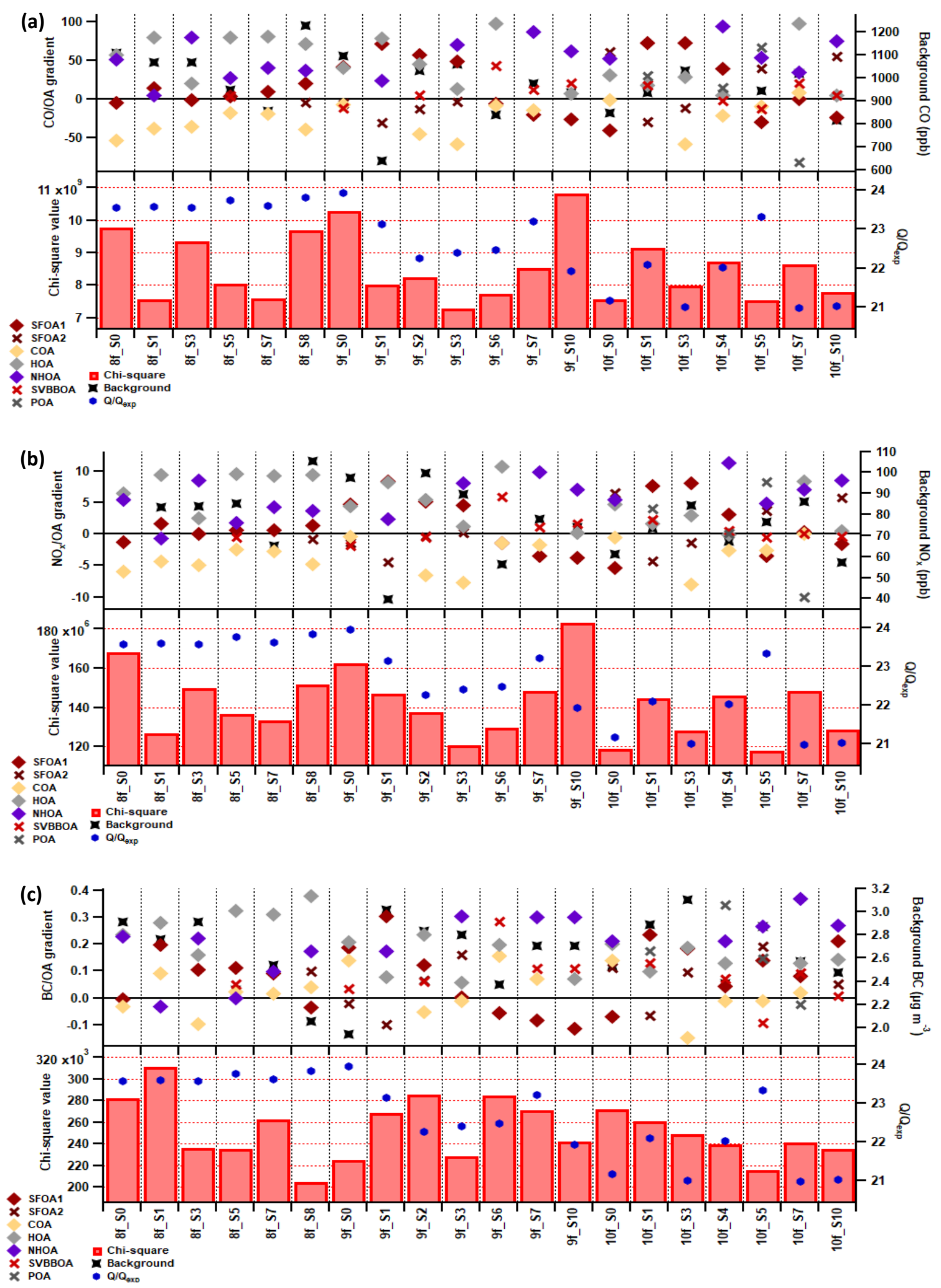

Figure S7 - Multilinear regression for Inorg-Org PMF solutions. Results are shown for the fit using (a) $\mathrm{CO}$, (b) $\mathrm{NO}_{\mathrm{x}}$ and (c) $\mathrm{BC}$ as external tracers. The chi-square value for the fit is shown using red bars and the $Q / Q_{\exp }$ with blue markers. Gradient contributions for each factor are shown alongside the background concentration for the tracer. 


\section{S4. Mean and standard deviations for species concentrations along with species concentration as a function of wind direction}

All values for concentration summary graphs, Figures 2 and 9, are shown in Error! Not a valid bookmark self-reference. and includes mean, median and standard deviations for the three measurement periods.

Table S2 - Mean and standard deviations for species concentrations during each measurement period

\begin{tabular}{|c|c|c|c|c|c|c|c|c|c|}
\hline \multirow[b]{2}{*}{ Species } & \multicolumn{3}{|c|}{ Pre-monsoon } & \multicolumn{3}{|c|}{ Monsoon } & \multicolumn{3}{|c|}{ Post-monsoon } \\
\hline & $\begin{array}{l}\text { Mean } \\
\left(\mu g m^{-3}\right)\end{array}$ & $\begin{array}{l}\text { Median } \\
\left(\mu g m^{-3}\right)\end{array}$ & $\begin{array}{l}\text { Standard } \\
\text { deviation } \\
\left(\mu \mathrm{g} \mathrm{m}^{-3}\right)\end{array}$ & $\begin{array}{l}\text { Mean } \\
\left(\mu g m^{-3}\right)\end{array}$ & $\begin{array}{l}\text { Median } \\
\left(\mu g m^{-3}\right)\end{array}$ & $\begin{array}{l}\text { Standard } \\
\text { deviation } \\
\left(\mu \mathrm{g} \mathrm{m}^{-3}\right)\end{array}$ & $\begin{array}{l}\text { Mean } \\
\left(\mu g m^{-3}\right)\end{array}$ & $\begin{array}{l}\text { Median } \\
\left(\mu g m^{-3}\right)\end{array}$ & $\begin{array}{l}\text { Standard } \\
\text { deviation } \\
\left(\mu \mathrm{g} \mathrm{m}^{-3}\right)\end{array}$ \\
\hline Chloride & 1.29 & 0.44 & 2.57 & 0.99 & 0.37 & 1.66 & 7.59 & 4.34 & 9.12 \\
\hline Ammonium & 4.16 & 3.90 & 2.35 & 3.75 & 3.39 & 2.04 & 8.51 & 6.88 & 5.98 \\
\hline Nitrate & 2.31 & 1.50 & 2.39 & 3.14 & 2.41 & 2.66 & 12.68 & 10.81 & 8.43 \\
\hline Sulphate & 13.05 & 12.71 & 6.39 & 11.29 & 9.90 & 5.56 & 10.82 & 9.53 & 6.66 \\
\hline$B C$ & 3.47 & 2.59 & 3.13 & 2.54 & 1.90 & 2.23 & 8.50 & 5.98 & 7.04 \\
\hline Organics & 29.16 & 26.12 & 22.96 & 24.98 & 21.43 & 16.63 & 100.69 & 80.58 & 72.32 \\
\hline$C O A$ & 7.84 & 5.61 & 8.73 & 2.83 & 1.79 & 3.57 & 9.13 & 6.69 & 11.63 \\
\hline NHOA & 0.83 & 0.00 & 2.46 & 0.76 & 0.19 & 1.33 & 12.09 & 3.96 & 18.85 \\
\hline SFOA & 1.16 & 0.07 & 3.51 & 1.36 & 0.50 & 3.33 & 16.32 & 8.68 & 23.44 \\
\hline$H O A$ & 5.13 & 3.07 & 6.90 & 6.55 & 4.84 & 5.62 & 16.18 & 8.02 & 20.44 \\
\hline SVBBOA & 0.53 & 0.00 & 1.18 & 0.01 & 0.00 & 0.11 & 18.85 & 14.97 & 15.37 \\
\hline LVOOA & 10.59 & 10.68 & 7.36 & 6.71 & 6.32 & 5.11 & 21.18 & 19.46 & 12.43 \\
\hline SVOOA & 3.26 & 1.57 & 4.76 & 6.81 & 5.41 & 5.81 & 7.38 & 6.11 & 6.21 \\
\hline
\end{tabular}

The polar graphs for AMS measured aerosol chemical species concentrations are presented in Figure S8 and show each 30-minute average measurement on the radius against the wind direction displayed as an angle. The pollution roses shown in the main manuscript do not show very distinct directional behaviours for the various species. The polar plots offer additional information especially about the highest values which are seen more clearly in Figure S8 and show the direction of possible high source contributors.

The diurnal cycle for chloride in the main manuscript shows a high morning peak at $~ 7-8$ a.m. (Figure 3). The pollution roses for each diurnal hour in Figure S9 shows this morning peak in more detail and suggests chloride originates from multiple directions. This helps to explain that chloride may be from multiple sources.

The polar graphs for PMF factors in Figure S10 are also used to help identify the wind directional preference of the highest outliers. The majority of the primary factors, NHOA, SFOA and COA, show strong outliers towards the south east which is the same wind direction for which there are large peaks in polyaromatic hydrocarbons. 

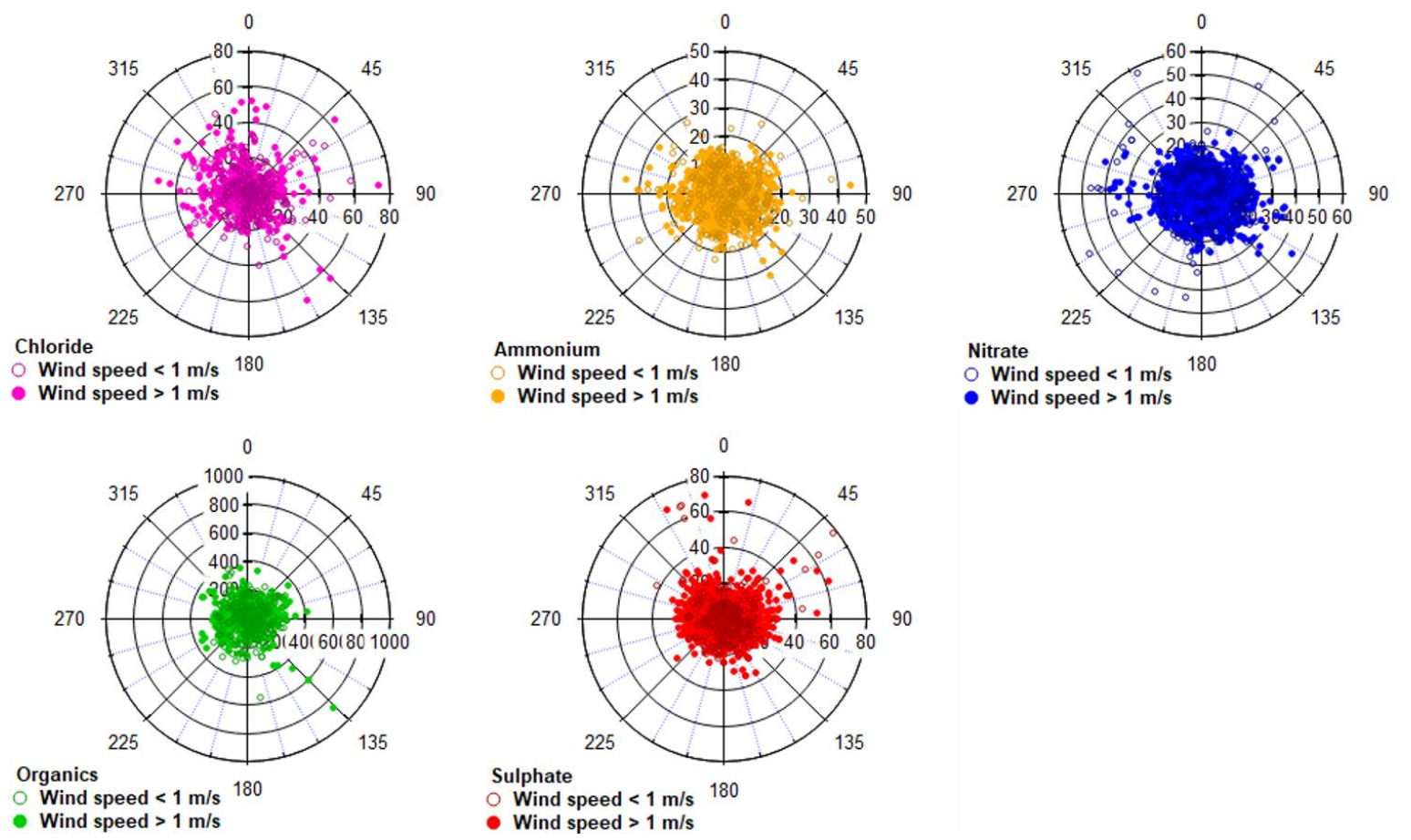

Wind speed $<1 \mathrm{~m} / \mathrm{s}$

- Wind speed $>1 \mathrm{~m} / \mathrm{s}$

Figure S8 - Polar graphs showing the concentrations by wind direction for chloride, ammonium, nitrate, sulphate and organics for all measurement periods combined. Each point represents a 5-minute measurement. Open symbols show concentrations for winds speeds $<1 \mathrm{~m} \mathrm{~s}^{-1}$ and closed symbols for wind speeds $>1 \mathrm{~m} \mathrm{~s}^{-1}$. 


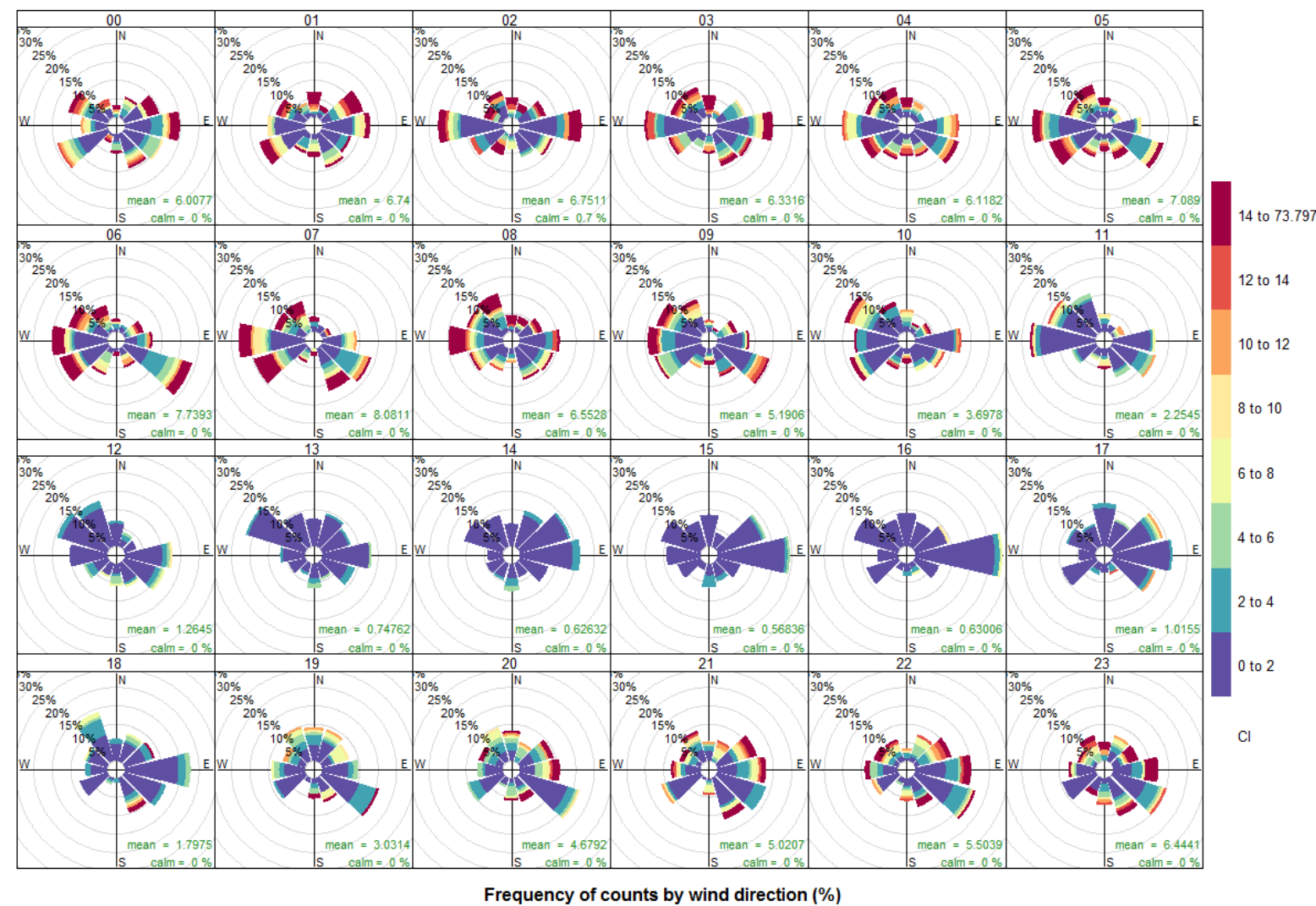

Figure S9 - Chloride pollution roses for each diurnal hour for all measurement periods combined, where the frequency of counts is shown as a percentage for each $30^{\circ}$ wind vector. The counts are divided into concentration bins based on the colour scale in the legend. Units are $\mu \mathrm{g} \mathrm{m}^{-3}$. 

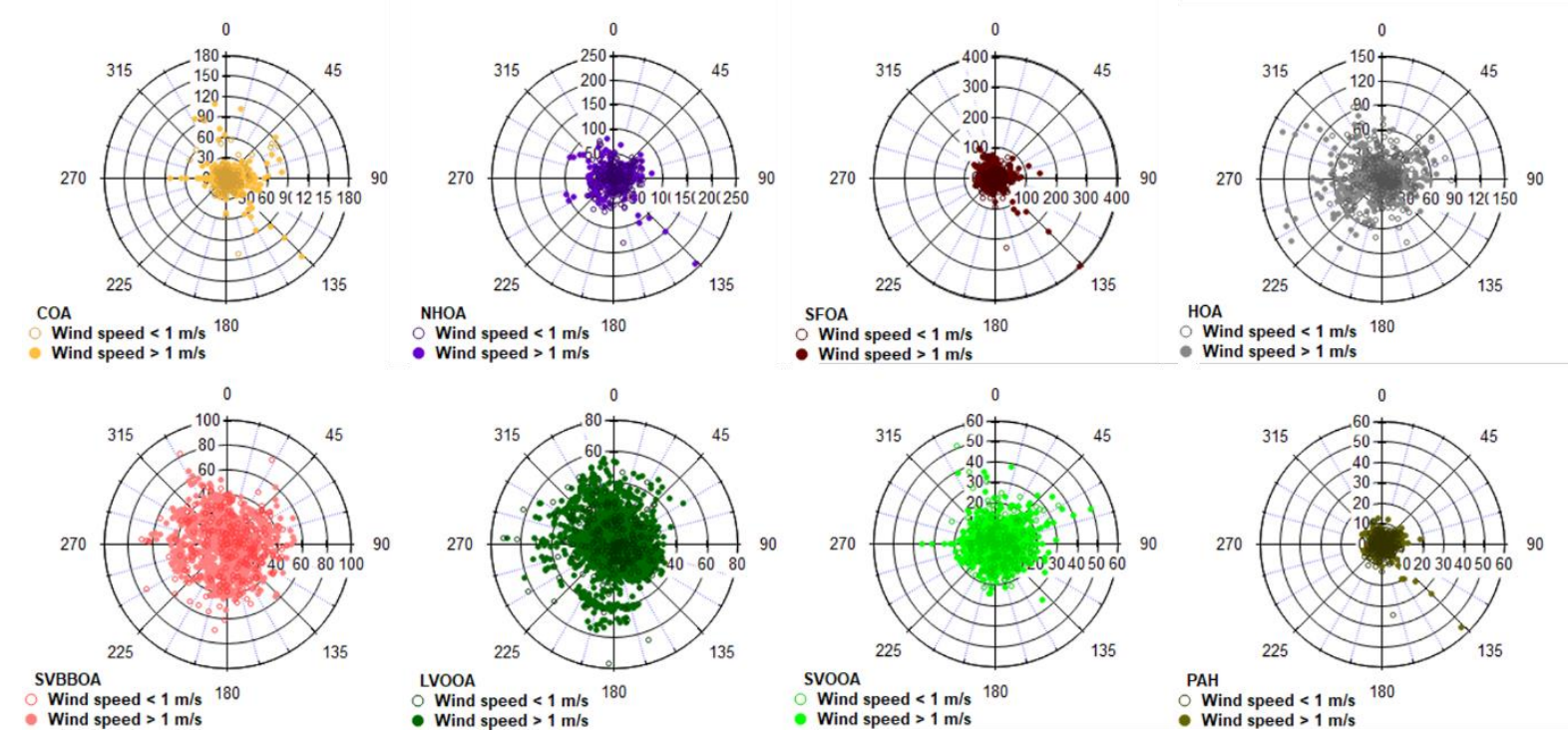

Figure S10 - Polar graphs showing the concentrations (in $\mu \mathrm{g} \mathrm{m}^{-3}$ ) by wind direction for the factor solutions: COA, NHOA, SFOA, HOA, SVBBOA, LVOOA and SVOOA. PAH polar graph shows uncalibrated concentrations (a.u.) by wind direction. Each point represents a 30-minute average measurement. Open symbols show concentrations for winds speeds $<1 \mathrm{~m} \mathrm{~s}^{-1}$ and closed symbols for wind speeds $>1 \mathrm{~m} \mathrm{~s}^{-1}$.

\section{S5. Determination of the contribution of nitrogen compounds within PMF factors}

As described in the main manuscript, the PMF factors NHOA and SVBBOA include a series of nitrogen-containing peaks. Figure S11 shows particular fragmentation patterns for each factor that can be used to distinguish the nitrogen-containing compounds responsible. The evidence collected in Section 3.3.3 suggest SVBBOA contains amide compounds whilst in Section 3.3.1 it is suggested that NHOA contains nitrile compounds. To further support the evidence that nitrile compounds exist within the NHOA signature, its time series was compared with known nitrile VOC compounds (Brilli et al., 2014) measured using the PTR-MS. The correlation results are shown in Figure S12 where NHOA shows strongest Pearson's $r$ correlations, compared to all PMF factors, with nitriles and other $\mathrm{C}_{\mathrm{x}} \mathrm{H}_{\mathrm{y}} \mathrm{N}_{\mathrm{z}}$ species. 

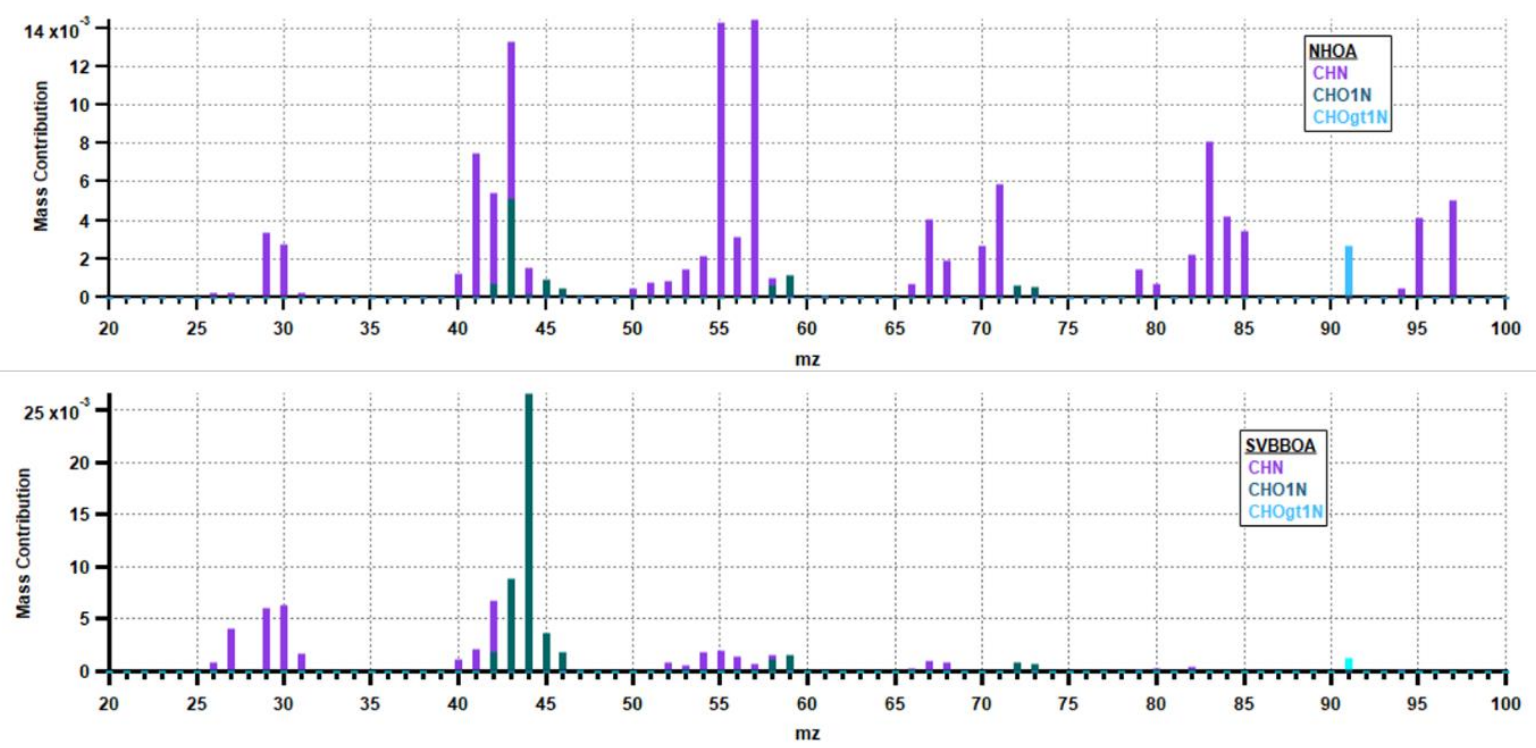

Figure S11 - Mass spectra for the NHOA and SVBBOA factors showing the different nitrogen-containing chemical moieties.

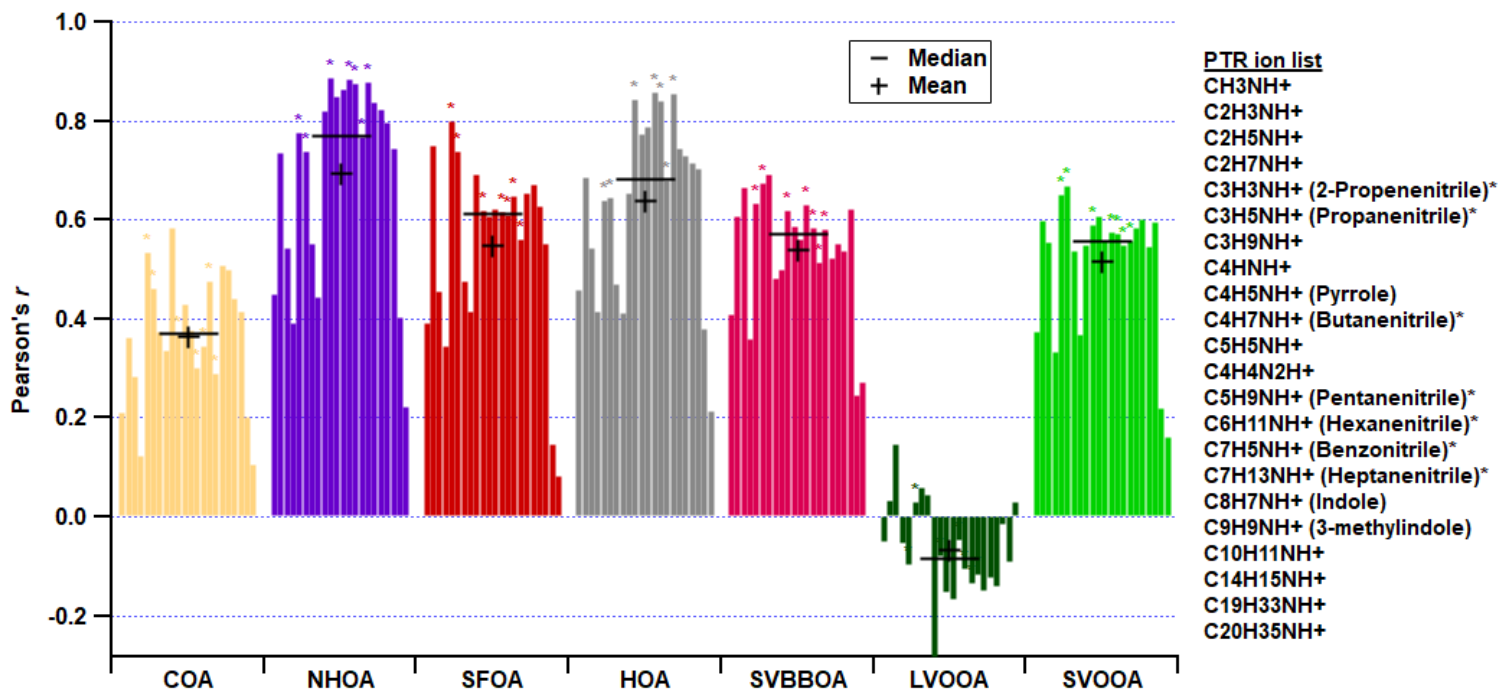

Figure S12 - Correlation coefficients between Org-only PMF factors with $\mathrm{C}_{\mathrm{x}} \mathrm{H}_{\mathrm{y}} \mathrm{N}_{\mathrm{z}}$ family species measured using the PTR-MS. Chemical names for species are assigned based on literature presented in Brilli et al. (2014) and species marked with * are known nitrile compounds. The PTR ion list corresponds to the correlations going from left to right for each factor.

\section{S6. Elemental ratio comparisons with literature using a Van Krevelen diagram}

The Van Krevelen (VK) diagram of $\mathrm{H}: \mathrm{C}$ ratio versus $\mathrm{O}: \mathrm{C}$ ratio has previously been used in AMS studies to determine the level of oxidation of measured organic aerosol (Heald et al., 
2010; Kroll et al., 2011; Ng et al., 2011; Canagaratna et al., 2015). The gradients in carbon oxidation states $\left(\overline{\mathrm{OS}}_{\mathrm{C}}\right)$ show how aerosol moves from a less oxidised form in the top left $\left(\overline{\mathrm{OS}}_{\mathrm{C}}\right.$ $=-2$ ) to a more oxidised form in the bottom right $\left(\overline{\mathrm{OS}}_{\mathrm{C}}=+2\right)$. It can also be used to estimate the reaction type that is occurring for the oxidation of aerosol. A gradient of zero with an increasing $\overline{\mathrm{OS}}_{\mathrm{C}}$, shows the addition of alcohol groups (R-COH) as there is an increase in both one oxygen and one hydrogen atom. The gradient of -1 shows the increase of two oxygen atoms for one hydrogen atom which suggests the addition of a carboxylic acid group or the simultaneous increase in both a carbonyl $(\mathrm{R}-\mathrm{C}=\mathrm{O})$ and an alcohol group $(\mathrm{R}-\mathrm{C}-\mathrm{OH})$. The final common reaction gradient is -2 which corresponds to an increase in a carbonyl $(\mathrm{R}-\mathrm{C}=\mathrm{O})$ group as two hydrogen atoms are lost for an increase in one oxygen atom.

The O:C and $\mathrm{H}: \mathrm{C}$ literature values for different PMF factors are shown in a VK diagram in Figure S13 and are tabulated in Table S2. The VK diagram shows a large spread of $\overline{\mathrm{OS}}_{\mathrm{C}}$ for the more oxidised PMF factors, such as LVOOA and SVOOA. Conversely, the primary factors, HOA and COA, both have a small window of $\overline{\mathrm{OS}}_{\mathrm{C}}$ but BBOA values can be variable. The PMF factors determined in this study in Delhi fall within similar compositional windows to literature with only the COA and SVBBOA factors showing significant differences. As discussed in the manuscript, the difference in Delhi COA is likely due to its high carboxylic acid content which is supported by its position being close to the -1 gradient in Figure S13. The SVBBOA factor is close to the zero gradient which may suggest it contains more alcohol functional groups. This is consistent with the time series of this factor having the strongest correlation (Pearson' $r=0.651$ ) with aerosol liquid water content (LWC) since alcohol groups tend to create compounds that are water soluble.

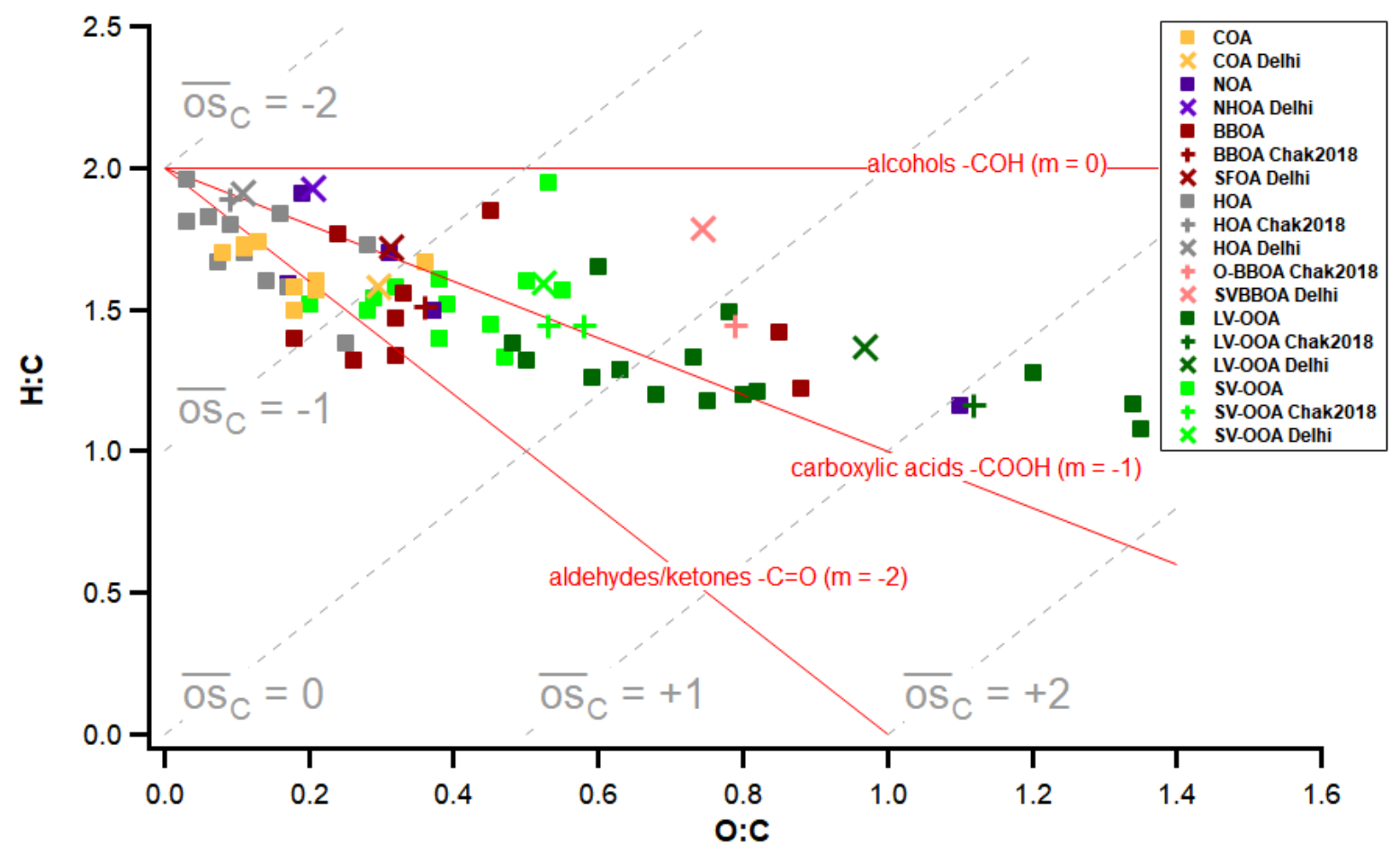

Figure S13 - Van Krevelen (VK) diagram for the mass spectra of the organic aerosol factors listed in Table S2. The data labelled with Chak2018 are from the study by Chakraborty et al. (2018) and those labelled with Delhi are values from this study. 
Table S3 - Literature values of O:C and H:C ratios for mass spectra of AMS organic aerosol factors from selected studies around the world.

\begin{tabular}{|c|c|c|c|c|c|c|c|c|c|c|c|c|c|}
\hline Literature & Country & O:C_SVVOOA & H:C_SVOOA & O:C_LVOOA & $H: C \_L V O O A$ & $O: C \_B B O A$ & $H: C_{-} B B O A$ & $O: C \_C O A$ & $H: C \_C O A$ & O:C_HOA & $H: C \_H O A$ & O:C_NOA & $H: C \_N O A$ \\
\hline $\begin{array}{l}\text { Ye et al. } \\
\text { (2017) }\end{array}$ & $\begin{array}{l}\text { Changzhou, } \\
\text { China }\end{array}$ & 0.53 & 1.95 & 1.2 & 1.28 & & & & & & & 0.19 & 1.91 \\
\hline $\begin{array}{l}\text { Timonen et } \\
\text { al. (2013) }\end{array}$ & $\begin{array}{l}\text { Helsinki, } \\
\text { Finland }\end{array}$ & 0.2 & 1.52 & 0.68 & 1.2 & 0.32 & 1.34 & & & 0.03 & 1.81 & & \\
\hline $\begin{array}{l}\text { Sun et al. } \\
\text { (2011a) }\end{array}$ & $\begin{array}{l}\text { Alabama, } \\
\text { USA }\end{array}$ & 0.5 & 1.6 & 0.6 & 1.65 & & & & & & & & \\
\hline $\begin{array}{l}\text { Sun et al. } \\
\text { (2011b) }\end{array}$ & $\begin{array}{l}\text { New York, } \\
\text { USA }\end{array}$ & 0.38 & 1.4 & 0.63 & 1.29 & & & 0.18 & 1.5 & 0.06 & 1.83 & 0.37 & 1.5 \\
\hline $\begin{array}{l}\text { Bottenus et } \\
\text { al. (2018) }\end{array}$ & $\begin{array}{l}\text { Washington, } \\
\text { USA }\end{array}$ & 0.29 & 1.54 & 0.5 & 1.32 & 0.26 & 1.32 & & & 0.074 & 1.67 & 0.17 & 1.59 \\
\hline $\begin{array}{l}\text { Zhang et al. } \\
\text { (2018) }\end{array}$ & $\begin{array}{l}\text { Northern } \\
\text { Himalayas, } \\
\text { China }\end{array}$ & & & 1.34 & 1.17 & 0.85 & 1.42 & & & & & 1.1 & 1.16 \\
\hline $\begin{array}{l}\text { Mohr et al. } \\
\text { (2012) }\end{array}$ & $\begin{array}{l}\text { Barcelona, } \\
\text { Spain }\end{array}$ & 0.32 & 1.58 & 0.75 & 1.18 & 0.24 & 1.77 & 0.21 & 1.57 & 0.03 & 1.96 & & \\
\hline $\begin{array}{l}\text { Schurman et } \\
\text { al. (2015) }\end{array}$ & $\begin{array}{l}\text { Colorado, } \\
\text { USA }\end{array}$ & 0.28 & 1.5 & 0.82 & 1.21 & 0.88 & 1.22 & & & & & & \\
\hline $\begin{array}{l}\mathrm{He} \text { et al. } \\
(2010)\end{array}$ & $\begin{array}{l}\text { lab-based } \\
\text { simulation } \\
\text { study }\end{array}$ & & & & & 0.18 & 1.4 & 0.08 & 1.7 & & & & \\
\hline $\begin{array}{l}\text { Huang et al. } \\
\text { (2010) }\end{array}$ & $\begin{array}{l}\text { Beijing, } \\
\text { China }\end{array}$ & 0.47 & 1.33 & 0.48 & 1.38 & & & 0.11 & 1.73 & 0.17 & 1.58 & & \\
\hline $\begin{array}{l}\mathrm{He} \text { et al. } \\
(2011)\end{array}$ & $\begin{array}{l}\text { Shenzhen, } \\
\text { China }\end{array}$ & 0.45 & 1.45 & 0.59 & 1.26 & 0.32 & 1.47 & & & 0.11 & 1.7 & & \\
\hline $\begin{array}{l}\text { Crippa et al. } \\
\text { (2013) }\end{array}$ & Paris, France & 0.39 & 1.52 & 0.73 & 1.33 & & & 0.13 & 1.74 & 0.16 & 1.84 & & \\
\hline $\begin{array}{l}\text { Ge et al. } \\
(2012)\end{array}$ & $\begin{array}{l}\text { California, } \\
\text { USA }\end{array}$ & & & & & 0.33 & 1.56 & 0.11 & 1.72 & 0.09 & 1.8 & & \\
\hline $\begin{array}{l}\text { Zhu et al. } \\
\text { (2016) }\end{array}$ & $\begin{array}{l}\text { Jiangsu, } \\
\text { China and } \\
\text { Hainan, } \\
\text { China }\end{array}$ & 0.55 & 1.57 & 1.35 & 1.08 & & & & & 0.28 & 1.73 & & \\
\hline $\begin{array}{l}\text { Chakraborty } \\
\text { et al. (2018) }\end{array}$ & Delhi, India & $\begin{array}{l}\text { SVOOA1 }=0.58 \\
\text { SVOOA2 }=0.53\end{array}$ & $\begin{array}{l}\text { SVOOA1 }=1.44 \\
\text { SVOOA2 }=1.44\end{array}$ & 1.12 & 1.16 & $\begin{array}{l}\mathrm{BBOA}=0.36 \\
\mathrm{O}-\mathrm{BBOA}=0.79\end{array}$ & $\begin{array}{l}\mathrm{BBOA}=1.51 \\
\mathrm{O}-\mathrm{BBOA}=1.44\end{array}$ & & & 0.09 & 1.89 & & \\
\hline This Study & Delhi, India & 0.52 & 1.59 & 0.97 & 1.37 & $\begin{array}{l}\mathrm{SFOA}=0.31 \\
\mathrm{SVBBOA}=0.74\end{array}$ & $\begin{array}{l}\text { SFOA }=1.72 \\
\text { SVBBOA }=1.79\end{array}$ & 0.30 & 1.58 & $\begin{array}{l}\mathrm{NHOA}=0.20 \\
\mathrm{HOA}=0.11\end{array}$ & $\begin{array}{l}\mathrm{NHOA}=1.93 \\
\mathrm{HOA}=1.91\end{array}$ & & \\
\hline
\end{tabular}




\section{S7. Monitoring Site Map}

The monitoring site $\left(28^{\circ} 39^{\prime} 51.8^{\prime \prime} \mathrm{N} 77^{\circ} 13^{\prime} 55.2^{\prime \prime} \mathrm{E}\right)$ at the Indira Gandhi Delhi Technical University for Women (IGDTUW) is shown in Figure S14 which is located 500-750 m from the Yamuna river. Two cremation sites are situated along the banks of the river, the largest of which is located east, and a smaller infant cremation site is southeast from the measurement site.
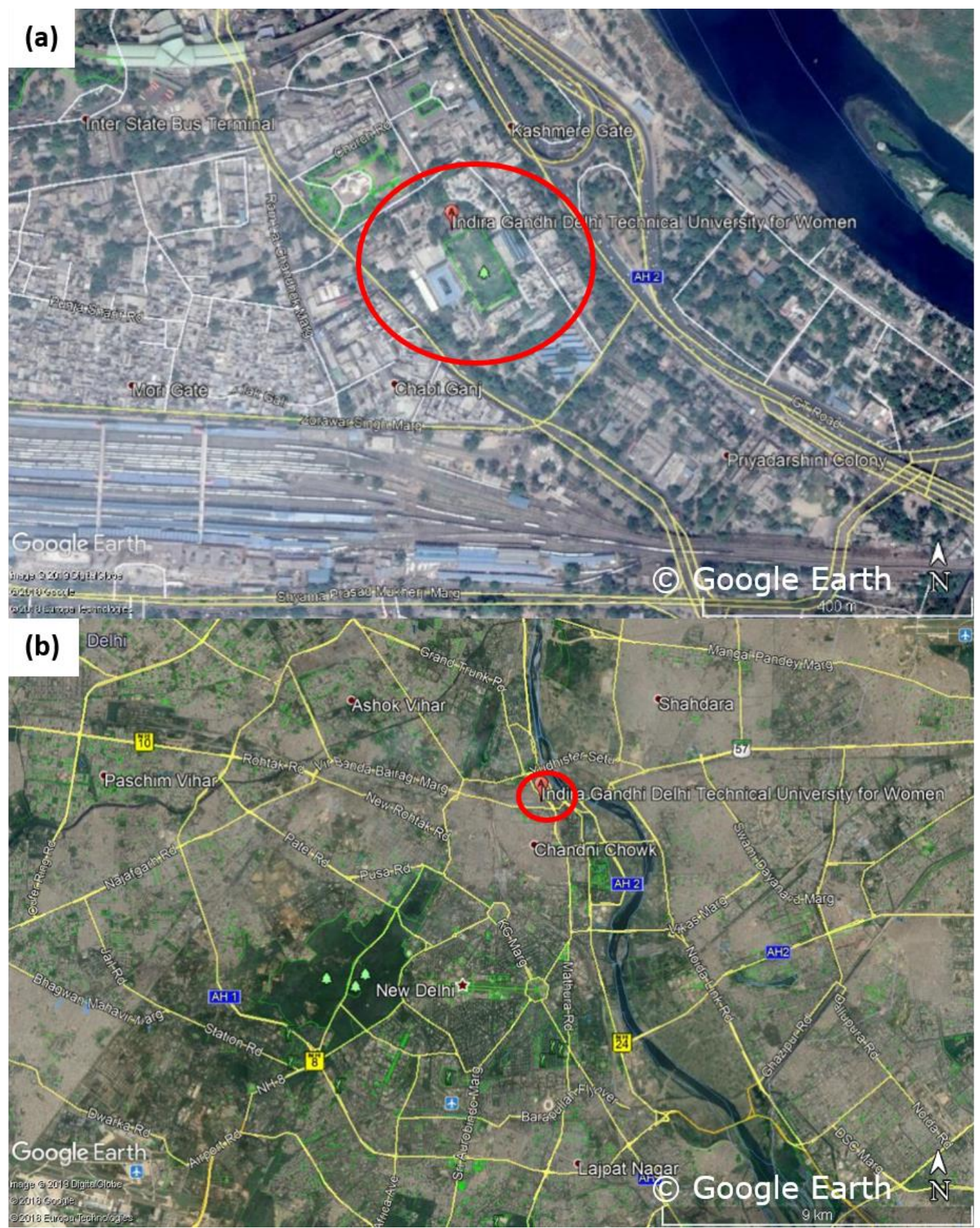

Figure S14 - Monitoring site map on (a) small and (b) large scale. The red circles show the monitoring site location. 


\section{S8. Inorganic-organic PMF solution results}

The PMF analysis on the inorganic and organic combined matrix gave a 9-factor solution which was chosen using the described method in Section S2. There are common factors between the organic-only and inorganic-organic PMF solutions. These include two traffic factors: a hydrocarbon-like organic aerosol factor (HOA) and an N-rich HOA factor (NHOA), a cooking OA (COA) factor and two secondary factors: semi-volatility oxygenated OA (SVOOA) and low volatility OOA (LVOOA). There are also two burning factors where one is similarly named solid fuel OA (SFOA) and the other is a Cl-rich SFOA factor (Cl-SFOA). There are also two factors containing mainly inorganic mass where one is rich in sulphate $\left(\mathrm{SO}_{4}-\mathrm{OA}\right)$ and the other is rich in nitrate $\left(\mathrm{NO}_{3}-\mathrm{OA}\right)$.

The factor mass profiles and their diurnal cycles during each measurement period are summarised in Figure S14. Their similarities to the organic-only solution and inorganic AMS species (nitrate, chloride and sulphate) are shown using time series and Pearson's $r$ correlations in Figure S15. Here, the primary factors and inorganic factors show strong correlations with the organic-only factors and inorganic AMS species, respectively. However, secondary factors such as SVOOA are weakly correlated. Therefore, this suggests that inorganic aerosol may be contributing to secondary factors and causing a difference in mass. Evidence of this is seen in Figure S15 where SVOOA is shown to have a large percentage of sulphate. There is also a difference in burning factors where the organic-only solution has a secondary (SVBBOA) and a primary (SFOA) factor compared to the two primary factors of the inorganic-organic solution. This is mostly due to the majority of the chloride aerosol being associated with burning aerosol in the Cl-SFOA factor. As described in Section 4.3 of the main manuscript, the factor SVBBOA is thought to be associated with crop residue burning transported to Delhi from outside the city. For the inorganic-organic solution, the increased burning $\mathrm{OA}$ in the post-monsoon during the crop burning cycle is also resolved via factor SFOA. However, most of the oxidised mass has moved into LVOOA which therefore creates two primary factors. SFOA is therefore likely to be associated to wood burning in general rather than being resolved due to a specific source such as crop residue burning. This is also evident in the pre-monsoon and monsoon periods where SFOA is generally higher in mass than the organic-only solution SVBBOA. 

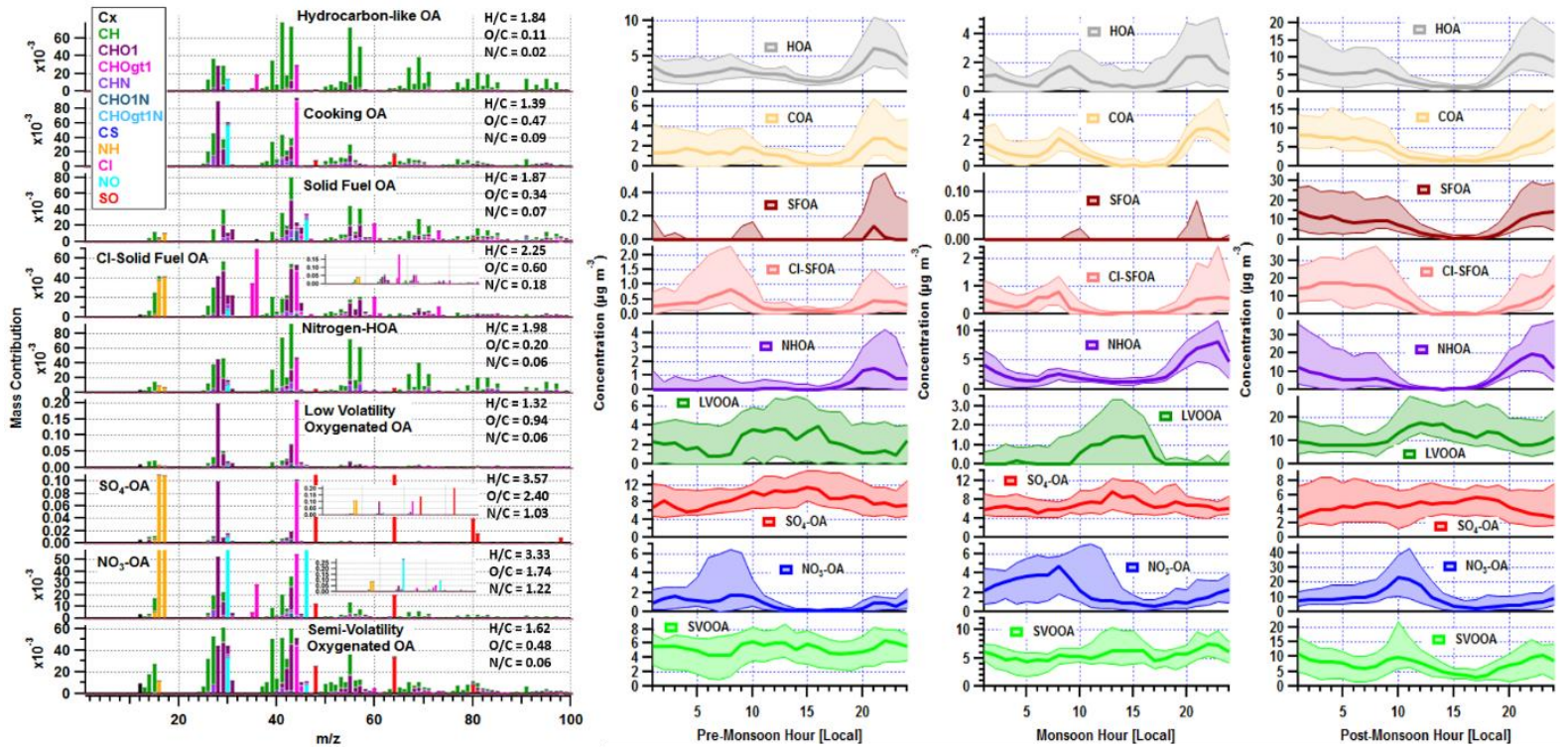

Figure S15 - Inorganic-organic PMF solution mass profiles along with the diurnal cycles for each measurement period. The mass profiles for Cl-solid fuel OA (Cl-SFOA), SO4$\mathrm{OA}$ and $\mathrm{NO}_{3}-\mathrm{OA}$ are dominated by certain peaks and their scales are adjusted to show the full spectrum. Small images of these factors on a larger scale are included to show the scale of the dominant peaks. 

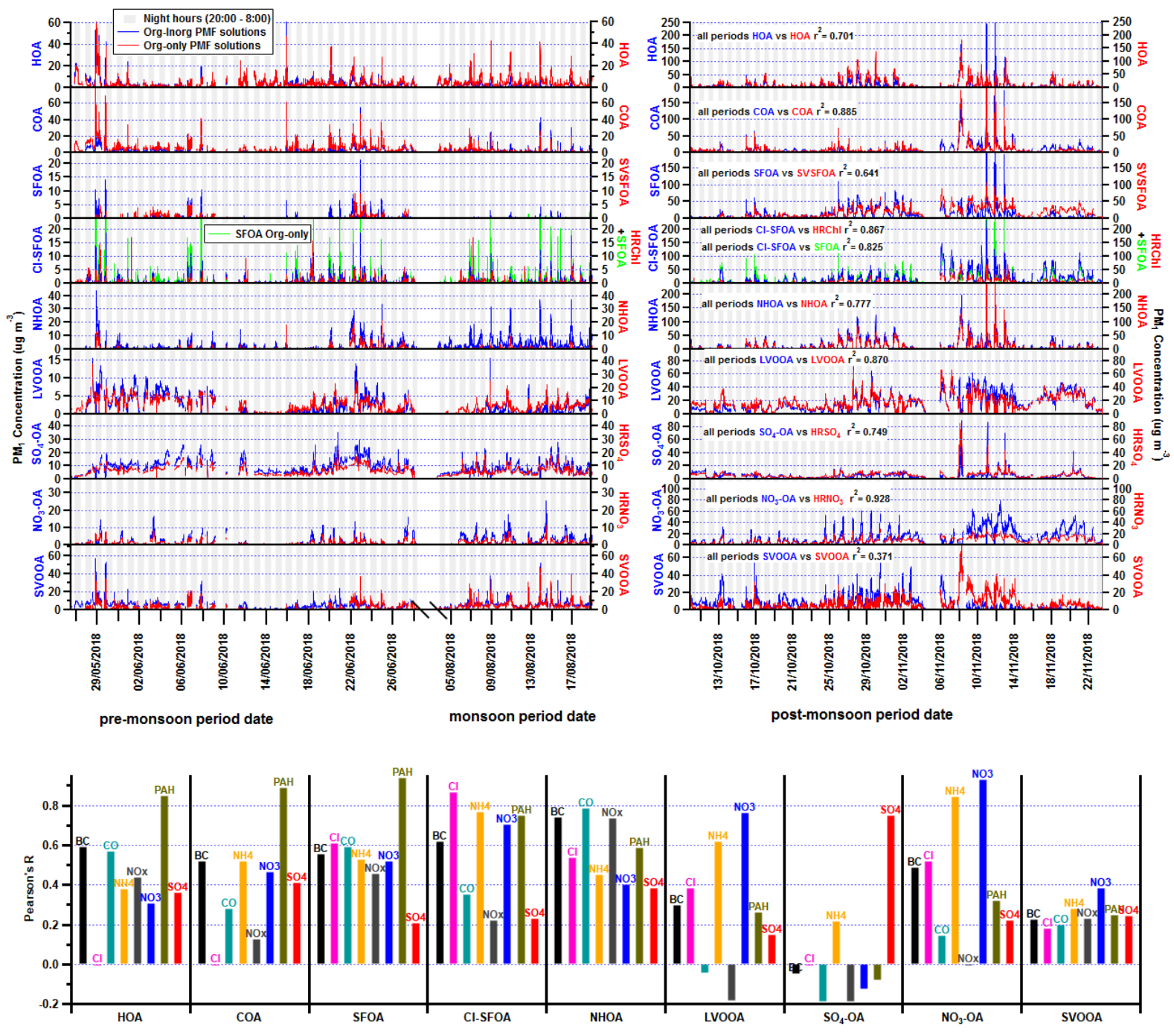

Figure S16 - Top panel: inorganic-organic PMF solution times series (blue) along with overlaid organic-only factor time series (red). The Pearson's $r$ correlations for each comparison is shown in the legend where only Cl-SFOA has two time series overlaid as it is similar to both SFOA (green) and measured chloride (red). Note: the scale changes between measurement periods and the left and right axes for LVOOA factors are also different in order to show similarities in their relative change. Bottom panel: Pearson's $r$ correlations between inorganic-organic solution factors and auxiliary measurements. 

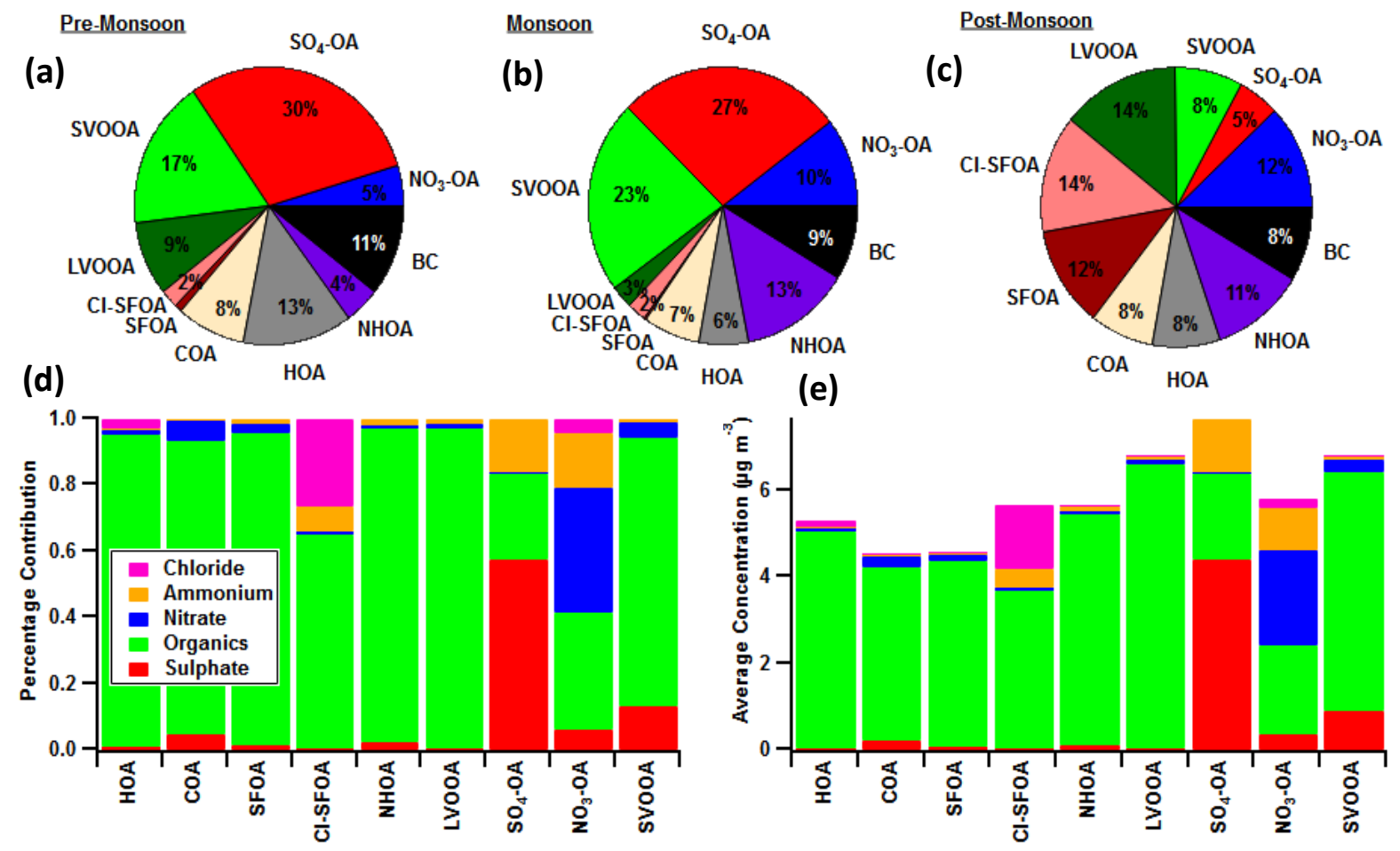

Figure S17 - Percentage contribution of PMF factors to total PM1 during each measurement ( $a, b$ and $c$ ), along with the percentage contribution of AMS species to each factor (d). The average concentration of AMS species within each factor is also summarised in (e).

\section{S9 - Organic nitrogen oxide monsoon diurnal cycle}

The elemental analysis in Section 3.4. shows the N:C diurnal cycle (Figure 13) which peaks at night during the monsoon period. The peak is suggested to be due to dark oxidation of volatile organic compounds via nitrate radicals. The $\mathrm{N}: \mathrm{C}$ diurnal cycle is shown along with the diurnal cycle for organic nitrogen oxide species (OrgNO) in Figure S16 which shows a variable rise in OrgNO during the morning hours (00:00-07:00). OrgNO is an estimate with a large margin of error $( \pm 20 \%)$ and this is shown using error bars (Kiendler-Scharr et al., 2016). The differences between the $\mathrm{N}: \mathrm{C}$ and OrgNO diurnal cycles during the morning may therefore be within the uncertainty range. There is also a general rise and fall in the interquartile range between 00:00 and 07:00 which follows the $\mathrm{N}: \mathrm{C}$ diurnal cycle. This may suggest that this rise is due to OrgNO formation via nitrate radical oxidation. 


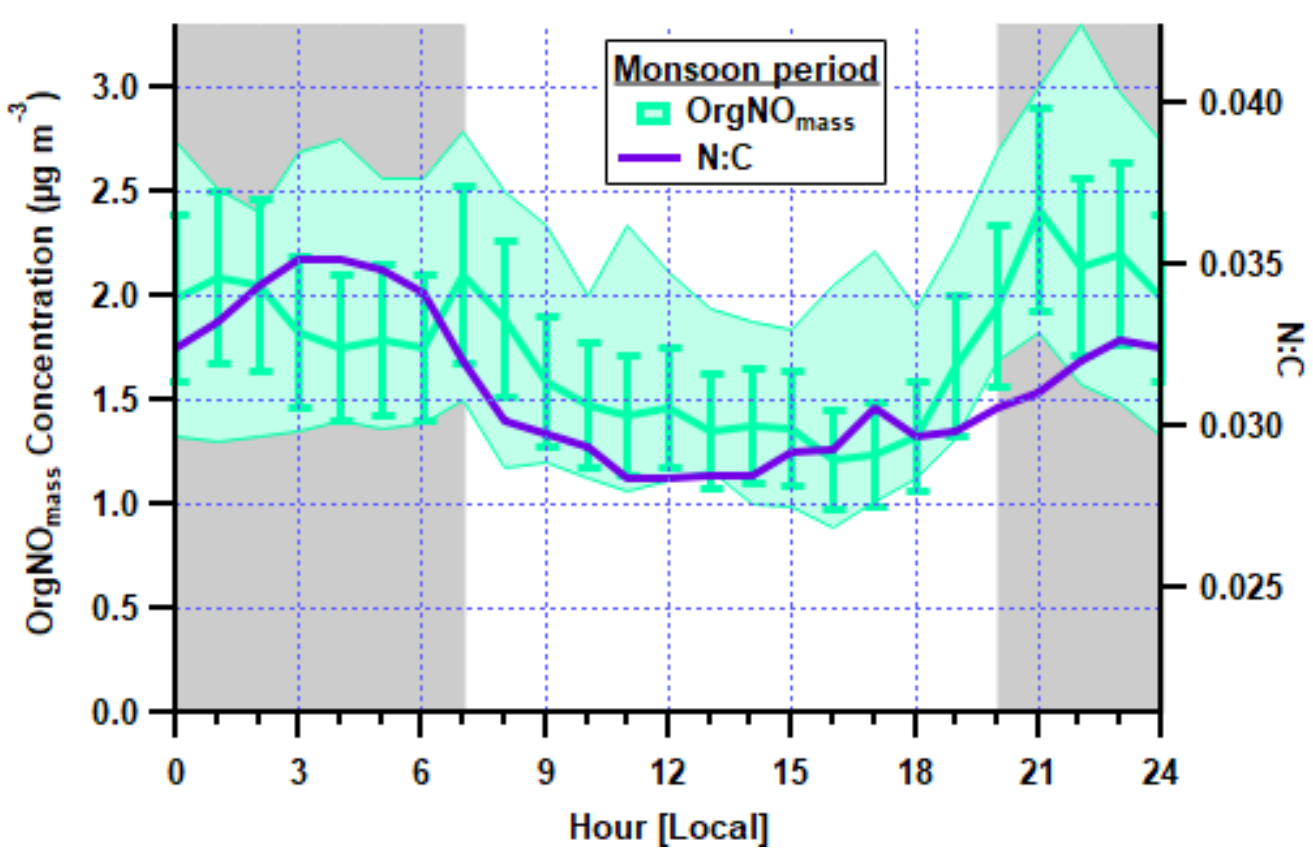

Figure S18 - Median diurnal cycles for organic nitrogen oxide species (OrgNOmass) and $\mathrm{N}: \mathrm{C}$ ratio. The OrgNOmass interquartile range is shown using shading and its uncertainty $( \pm 20 \%)$ is shown using error bars. The grey shading indicates the dark hours of the day.

\section{References}

Aiken, A. C., Salcedo, D., Cubison, M. J., Huffman, J. A., DeCarlo, P. F., Ulbrich, I. M., Docherty, K. S., Sueper, D., Kimmel, J. R., Worsnop, D. R., Trimborn, A., Northway, M., Stone, E. A., Schauer, J. J., Volkamer, R. M., Fortner, E., de Foy, B., Wang, J., Laskin, A., Shutthanandan, V., Zheng, J., Zhang, R., Gaffney, J., Marley, N. A., Paredes-Miranda, G., Arnott, W. P., Molina, L. T., Sosa, G. and Jimenez, J. L.: Mexico City aerosol analysis during MILAGRO using high resolution aerosol mass spectrometry at the urban supersite (T0) - Part 1: Fine particle composition and organic source apportionment, Atmos. Chem. Phys., 9(17), 6633-6653, doi:10.5194/acp-9-6633-2009, 2009.

Allan, J. D., Williams, P. I., Morgan, W. T., Martin, C. L., Flynn, M. J., Lee, J., Nemitz, E., Phillips, G. J., Gallagher, M. W. and Coe, H.: Contributions from transport, solid fuel burning and cooking to primary organic aerosols in two UK cities, Atmos. Chem. Phys., 10(2), 647668, doi:10.5194/acp-10-647-2010, 2010.

Bottenus, C. L. H., Massoli, P., Sueper, D., Canagaratna, M. R., VanderSchelden, G., Jobson, B. T. and VanReken, T. M.: Identification of amines in wintertime ambient particulate material using high resolution aerosol mass spectrometry, Atmos. Environ., 180, 173-183, doi:10.1016/j.atmosenv.2018.01.044, 2018.

Brilli, F., Gioli, B., Ciccioli, P., Zona, D., Loreto, F., Janssens, I. A. and Ceulemans, R.: Proton Transfer Reaction Time-of-Flight Mass Spectrometric (PTR-TOF-MS) determination of volatile organic compounds (VOCs) emitted from a biomass fire developed under stable nocturnal conditions, Atmos. Environ., 97, 54-67, doi:10.1016/j.atmosenv.2014.08.007, 2014.

Canagaratna, M. R., Jimenez, J. L., Kroll, J. H., Chen, Q., Kessler, S. H., Massoli, P., 
Hildebrandt Ruiz, L., Fortner, E., Williams, L. R., Wilson, K. R., Surratt, J. D., Donahue, N. M., Jayne, J. T. and Worsnop, D. R.: Elemental ratio measurements of organic compounds using aerosol mass spectrometry: Characterization, improved calibration, and implications, Atmos. Chem. Phys., 15(1), 253-272, doi:10.5194/acp-15-253-2015, 2015.

Chakraborty, A., Mandariya, A. K., Chakraborti, R., Gupta, T. and Tripathi, S. N.: Realtime chemical characterization of post monsoon organic aerosols in a polluted urban city: Sources, composition, and comparison with other seasons, Environ. Pollut., 232, 310-321, doi:10.1016/j.envpol.2017.09.079, 2018.

Crippa, M., El Haddad, I., Slowik, J. G., Decarlo, P. F., Mohr, C., Heringa, M. F., Chirico, R., Marchand, N., Sciare, J., Baltensperger, U. and Prévôt, A. S. H.: Identification of marine and continental aerosol sources in Paris using high resolution aerosol mass spectrometry, J. Geophys. Res. Atmos., 118(4), 1950-1963, doi:10.1002/jgrd.50151, 2013.

Docherty, K. S., Aiken, A. C., Huffman, J. A., Ulbrich, I. M., Decarlo, P. F., Sueper, D., Worsnop, D. R., Snyder, D. C., Peltier, R. E., Weber, R. J., Grover, B. D., Eatough, D. J., Williams, B. J., Goldstein, A. H., Ziemann, P. J. and Jimenez, J. L.: The 2005 Study of Organic Aerosols at Riverside (SOAR-1): Instrumental intercomparisons and fine particle composition, Atmos. Chem. Phys., 11(23), 12387-12420, doi:10.5194/acp-11-12387-2011, 2011.

Ge, X., Setyan, A., Sun, Y. and Zhang, Q.: Primary and secondary organic aerosols in Fresno, California during wintertime: Results from high resolution aerosol mass spectrometry, J. Geophys. Res. Atmos., 117(D19301), doi:10.1029/2012JD018026, 2012.

He, L. Y., Lin, Y., Huang, X. F., Guo, S., Xue, L., Su, Q., Hu, M., Luan, S. J. and Zhang, Y. H.: Characterization of high-resolution aerosol mass spectra of primary organic aerosol emissions from Chinese cooking and biomass burning, Atmos. Chem. Phys., 10(23), 1153511543, doi:10.5194/acp-10-11535-2010, 2010.

He, L. Y., Huang, X. F., Xue, L., Hu, M., Lin, Y., Zheng, J., Zhang, R. and Zhang, Y. H.: Submicron aerosol analysis and organic source apportionment in an urban atmosphere in Pearl River Delta of China using high-resolution aerosol mass spectrometry, J. Geophys. Res. Atmos., 116(12), 1-15, doi:10.1029/2010JD014566, 2011.

Heald, C. L., Kroll, J. H., Jimenez, J. L., Docherty, K. S., Decarlo, P. F., Aiken, A. C., Chen, Q., Martin, S. T., Farmer, D. K. and Artaxo, P.: A simplified description of the evolution of organic aerosol composition in the atmosphere, Geophys. Res. Lett., 37(8), doi:10.1029/2010GL042737, 2010.

Huang, X. F., He, L. Y., Hu, M., Canagaratna, M. R., Sun, Y., Zhang, Q., Zhu, T., Xue, L., Zeng, L. W., Liu, X. G., Zhang, Y. H., Jayne, J. T., Ng, N. L. and Worsnop, D. R.: Highly time-resolved chemical characterization of atmospheric submicron particles during 2008 Beijing Olympic games using an aerodyne high-resolution aerosol mass spectrometer, Atmos. Chem. Phys., 10(18), 8933-8945, doi:10.5194/acp-10-8933-2010, 2010.

Kiendler-Scharr, A., Mensah, A. A., Friese, E., Topping, D., Nemitz, E., Prevot, A. S. H., Äijälä, M., Allan, J., Canonaco, F., Canagaratna, M., Carbone, S., Crippa, M., Dall Osto, M., Day, D. A., De Carlo, P., Di Marco, C. F., Elbern, H., Eriksson, A., Freney, E., Hao, L., Herrmann, H., Hildebrandt, L., Hillamo, R., Jimenez, J. L., Laaksonen, A., McFiggans, G., Mohr, C., O’Dowd, C., Otjes, R., Ovadnevaite, J., Pandis, S. N., Poulain, L., Schlag, P., Sellegri, K., Swietlicki, E., Tiitta, P., Vermeulen, A., Wahner, A., Worsnop, D. and Wu, H. C.: Ubiquity of organic nitrates from nighttime chemistry in the European submicron aerosol, 
Geophys. Res. Lett., 43(14), 7735-7744, doi:10.1002/2016GL069239, 2016.

Kroll, J. H., Donahue, N. M., Jimenez, J. L., Kessler, S. H., Canagaratna, M. R., Wilson, K. R., Altieri, K. E., Mazzoleni, L. R., Wozniak, A. S., Bluhm, H., Mysak, E. R., Smith, J. D., Kolb, C. E. and Worsnop, D. R.: Carbon oxidation state as a metric for describing the chemistry of atmospheric organic aerosol, Nat. Chem., 3(2), 133-139, doi:10.1038/nchem.948, 2011.

Mohr, C., DeCarlo, P. F., Heringa, M. F., Chirico, R., Slowik, J. G., Richter, R., Reche, C., Alastuey, A., Querol, X., Seco, R., Peñuelas, J., Jiménez, J. L., Crippa, M., Zimmermann, R., Baltensperger, U. and Prévôt, A. S. H.: Identification and quantification of organic aerosol from cooking and other sources in Barcelona using aerosol mass spectrometer data, Atmos. Chem. Phys., 12(4), 1649-1665, doi:10.5194/acp-12-1649-2012, 2012.

Ng, N. L., Canagaratna, M. R., Jimenez, J. L., Chhabra, P. S., Seinfeld, J. H. and Worsnop, D. R.: Changes in organic aerosol composition with aging inferred from aerosol mass spectra, Atmos. Chem. Phys., 11(13), 6465-6474, doi:10.5194/acp-11-6465-2011, 2011.

Reyes-Villegas, E., Green, D. C., Priestman, M., Canonaco, F., Coe, H., Prévôt, A. S. H. and Allan, J. D.: Organic aerosol source apportionment in London 2013 with ME-2: Exploring the solution space with annual and seasonal analysis, Atmos. Chem. Phys., 16(24), 1554515559, doi:10.5194/acp-16-15545-2016, 2016.

Schurman, M. I., Lee, T., Sun, Y., Schichtel, B. A., Kreidenweis, S. M. and Collett, J. L.: Investigating types and sources of organic aerosol in Rocky Mountain National Park using aerosol mass spectrometry, Atmos. Chem. Phys., 15(2), 737-752, doi:10.5194/acp-15-7372015, 2015.

Sun, Y., Zhang, Q., Zheng, M., Ding, X., Edgerton, E. S. and Wang, X.: Characterization and Source Apportionment of Water-Soluble Organic Matter in Atmospheric Fine Particles (PM 2.5 ) with High-Resolution Aerosol Mass Spectrometry and GC-MS, Environ. Sci. Technol., 45(11), 4854-4861, doi:10.1021/es200162h, 2011a.

Sun, Y., Du, W., Fu, P., Wang, Q., Li, J., Ge, X., Zhang, Q., Zhu, C., Ren, L., Xu, W., Zhao, J., Han, T., Worsnop, D. R. and Wang, Z.: Primary and secondary aerosols in Beijing in winter: Sources, variations and processes, Atmos. Chem. Phys., 16(13), 8309-8329, doi:10.5194/acp-16-8309-2016, 2016.

Sun, Y. L., Zhang, Q., Schwab, J. J., Demerjian, K. L., Chen, W. N., Bae, M. S., Hung, H. M., Hogrefe, O., Frank, B., Rattigan, O. V. and Lin, Y. C.: Characterization of the sources and processes of organic and inorganic aerosols in New York city with a high-resolution time-of-flight aerosol mass apectrometer, Atmos. Chem. Phys., 11(4), 1581-1602, doi:10.5194/acp-11-1581-2011, $2011 \mathrm{~b}$.

Timonen, H., Carbone, S., Aurela, M., Saarnio, K., Saarikoski, S., Ng, N. L., Canagaratna, M. R., Kulmala, M., Kerminen, V. M., Worsnop, D. R. and Hillamo, R.: Characteristics, sources and water-solubility of ambient submicron organic aerosol in springtime in Helsinki, Finland, J. Aerosol Sci., 56, 61-77, doi:10.1016/j.jaerosci.2012.06.005, 2013.

Ulbrich, I. M., Canagaratna, M. R., Zhang, Q., Worsnop, D. R. and Jimenez, J. L.: Interpretation of organic components from Positive Matrix Factorization of aerosol mass spectrometric data, Atmos. Chem. Phys., 9(9), 2891-2918, doi:10.5194/acp-9-2891-2009, 2009.

Ye, Z., Liu, J., Gu, A., Feng, F., Liu, Y., Bi, C., Xu, J., Li, L., Chen, H., Chen, Y., Dai, L., 
Zhou, Q. and Ge, X.: Chemical characterization of fine particulate matter in Changzhou, China, and source apportionment with offline aerosol mass spectrometry, Atmos. Chem. Phys., 17(4), 2573-2592, doi:10.5194/acp-17-2573-2017, 2017.

Young, D. E., Allan, J. D., Williams, P. I., Green, D. C., Harrison, R. M., Yin, J., Flynn, M. J., Gallagher, M. W. and Coe, H.: Investigating a two-component model of solid fuel organic aerosol in London: Processes, PM1 contributions, and seasonality, Atmos. Chem. Phys., 15(5), 2429-2443, doi:10.5194/acp-15-2429-2015, 2015.

Zhang, X., Xu, J., Kang, S., Liu, Y. and Zhang, Q.: Chemical characterization of long-range transport biomass burning emissions to the Himalayas: Insights from high-resolution aerosol mass spectrometry, Atmos. Chem. Phys., 18(7), 4617-4638, doi:10.5194/acp-18-4617-2018, 2018.

Zhu, Q., He, L. Y., Huang, X. F., Cao, L. M., Gong, Z. H., Wang, C., Zhuang, X. and Hu, M.: Atmospheric aerosol compositions and sources at two national background sites in northern and southern China, Atmos. Chem. Phys., 16(15), 10283-10297, doi:10.5194/acp-16-102832016, 2016. 